Old Dominion University

ODU Digital Commons

OEAS Faculty Publications

Ocean, Earth \& Atmospheric Sciences

$1-2017$

\title{
Elevated Trace Metal Content of Prokaryotic Communities Associated with Marine Oxygen Deficient Zones
}

\author{
Daniel C. Ohnemus
}

Sara Rauschenberg

Gregory A. Cutter

Old Dominion University, gcutter@odu.edu

Jessica N. Fitzsimmons

Robert M. Sherrell

See next page for additional authors

Follow this and additional works at: https://digitalcommons.odu.edu/oeas_fac_pubs

Part of the Marine Biology Commons, and the Oceanography Commons

\section{Repository Citation}

Ohnemus, Daniel C.; Rauschenberg, Sara; Cutter, Gregory A.; Fitzsimmons, Jessica N.; Sherrell, Robert M.; and Twining, Benjamin S., "Elevated Trace Metal Content of Prokaryotic Communities Associated with Marine Oxygen Deficient Zones" (2017). OEAS

Faculty Publications. 217.

https://digitalcommons.odu.edu/oeas_fac_pubs/217

\section{Original Publication Citation}

Ohnemus, D. C., Rauschenberg, S., Cutter, G. A., Fitzsimmons, J. N., Sherrell, R. M., \& Twining, B. S. (2017). Elevated trace metal content of prokaryotic communities associated with marine oxygen deficient zones. Limnology and Oceanography, 62(1), 3-25. doi:10.1002/lno.10363 
Authors

Daniel C. Ohnemus, Sara Rauschenberg, Gregory A. Cutter, Jessica N. Fitzsimmons, Robert M. Sherrell, and Benjamin S. Twining 


\title{
Elevated trace metal content of prokaryotic communities associated with marine oxygen deficient zones
}

\author{
Daniel C. Ohnemus, ${ }^{1 *}$ Sara Rauschenberg, ${ }^{1}$ Gregory A. Cutter, ${ }^{2}$ Jessica N. Fitzsimmons, ${ }^{3,4}$ \\ Robert M. Sherrell, ${ }^{3,5}$ Benjamin S. Twining ${ }^{1}$ \\ ${ }^{1}$ Bigelow Laboratory for Ocean Sciences, East Boothbay, Maine \\ ${ }^{2}$ Department of Ocean, Earth, and Atmospheric Sciences, Old Dominion University, Norfolk, Virginia \\ ${ }^{3}$ Department of Marine and Coastal Sciences, Rutgers University, New Brunswick, New Jersey \\ ${ }^{4}$ Now at Department of Oceanography, Texas A\&M University, College Station, Texas \\ ${ }^{5}$ Department of Earth and Planetary Sciences, Rutgers University, Piscataway, New Jersey
}

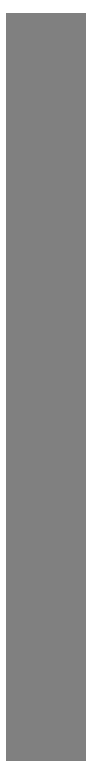

\begin{abstract}
Little is known about the trace metal content of marine prokaryotes, in part due to their co-occurrence with more abundant particulate phases in the upper ocean, such as phytoplankton and biogenic detritus, lithogenic minerals, and authigenic Mn and Fe oxyhydroxides. We attempt to isolate these biomass signals in particulate data from the US GEOTRACES Eastern Pacific Zonal Transect (cruise GP16) in the Eastern Tropical South Pacific (ETSP), which exhibited consistent maxima in P and other bioactive trace metals, and minima in particulate $\mathrm{Mn}$, in the oxygen deficient zones (ODZs) of 13 stations. Nitrite maxima and nitrate deficits indicated the presence of denitrifying prokaryotic biomass within ETSP ODZs, and deep secondary fluorescence maxima at the upper ODZ boundaries of 10 stations also suggested the presence of low-light, autotrophic communities. ODZs were observed as far west as $99^{\circ} \mathrm{W}$, more than $2300 \mathrm{~km}$ from the South American coast, where eolian lithogenic and lateral/resuspended sedimentary inputs were negligible, presenting a unique opportunity to examine prokaryotic metal stoichiometries. ODZ particulate P maxima can rival gyre mixed layer biomass concentrations, are highly sensitive to oxygen, and are in excess of amounts scavengable by local Fe oxyhydroxides and acid-volatile sulfides. Even after correction for lithogenic and ferruginous-scavenged metals, ODZ P-maxima are often enriched in $\mathrm{Cd}, \mathrm{Co}, \mathrm{Cu}, \mathrm{Ni}, \mathrm{V}$, and $\mathrm{Zn}$, exhibiting particulate trace metal ratios to $\mathrm{P}$ that exceed mixed layer biomass ratios by factors of 2-9. ODZ prokaryotic communities may be largely hidden, TM-rich pools involved in the marine cycles of these bioactive trace metals.
\end{abstract}

Oxygen deficient zones (ODZs) of the Arabian Sea and the Eastern Tropical North and South Pacific (ETNP, ETSP) are sites of diverse microbial productivity that mediate redox cycling of $\mathrm{N}, \mathrm{S}$, and $\mathrm{C}$ in the virtual absence of oxygen (Ulloa et al. 2012). These zones consist of functionally anoxic cores and associated oxic-suboxic transition zones at the bottom of the upper oxycline, hosting a complex cascade of aerobic and anaerobic microbially mediated biogeochemical processes (Tiano et al. 2014). Significant attention has been paid to ODZs in recent decades because of their importance to the global cycles of $\mathrm{C}$ and $\mathrm{N}$, their production of the greenhouse gas $\mathrm{N}_{2} \mathrm{O}$, and their ongoing expansion and shoaling in response to climate change (Whitney et al. 2007; Stramma et al. 2010, 2012; Wright et al. 2012).

*Correspondence: dan@bigelow.org
Low-oxygen marine environments have long been known to contain particle maxima that were originally termed "intermediate nepheloid layers" (Pak et al. 1980; Spinrad et al. 1989), and several recent studies have highlighted the likely biotic nature of these maxima within the ETSP ODZ. Whitmire et al. (2009) used drifter-collected transects of the Peruvian upwelling region to demonstrate consistent particle maxima in association with the upper edge of the ODZ and also noted a low-light, secondary deep chlorophyll maximum at stations where the ODZ is shallow enough to impinge on the euphotic zone. Using ultra-low detection limit oxygen sensors, Tiano et al. (2014) demonstrated that ODZ-associated secondary fluorescence maxima maintain oxygen concentrations in the low nanomolar range, suggesting that the autotrophic upper ODZ layer may diurnally cycle between anoxic and vanishingly oxic conditions, indicating a tight coupling between anaerobic and aerobic 
processes. Flow cytometry and genetic phylogeny conducted at ODZ sites have identified populations $\left(10^{3}\right.$ to $10^{4}$ cells $\mathrm{mL}^{-1}$ ) of low-light-adapted cyanobacteria in this fluorescent zone, primarily Prochlorococcus (Goericke et al. 2000; Lavin et al. 2010). Acoustic backscatter of larger, oxycline-associated biota (zooplankton and larger eukaryotes) can be a reliable means to observe the base of the upper oxycline (Bertrand et al. 2010) though vertically migrating zooplankton, which feed on settling particulate organic material (POM) (Wishner et al. 1995; Williams et al. 2014), are typically excluded from the ODZ itself by the lack of oxygen (Wishner et al. 2013). Increased cell counts and particle loads in the anoxic ODZ core, by comparison, are correlated with the intensity of its denitrifying activity (Naqvi et al. 1993). Taken together, the upper ODZ appears to be a maximum for autotrophic cyanobacteria and annamox activity (Galán et al. 2009), while heterotrophic denitrification dominates within the ODZ core (Ulloa et al. 2012).

Regardless of the absolute identities of the underlying communities, ODZs are sites of intense and uniquely prokaryotic productivity in the near-micron size fraction (Lavin et al. 2010; Close et al. 2014). Furthermore, the absence of an underlying sulfidic zone, as is consistently present beneath the suboxic zones of the Black Sea and Cariaco Basin, precludes the intense and persistent diffusive metal fluxes associated with euxinic environments (Lewis and Landing 1991, 1992; Ho et al. 2004; Yiğiterhan et al. 2011). This makes the ETSP ODZ, especially offshore away from continental shelf influences, a good environment for examining the elemental composition of prokaryotic communities in the relative absence of lithogenic particles, eukaryotic phytoplankton, and detrital mixed layer biomass. These interfering phases typically mask prokaryotic biomass signatures in the surface mixed layer and near-shore environments. Particulate interferences unique to the suboxic water column, such as authigenic Fe and Mn oxyhydroxides that form and cycle there (Senn et al. 2015), do require special consideration, however.

Examinations of bioactive particulate trace metals (pTMs) in prokaryotes have typically focused on trace metal toxicity, e.g., in human-influenced coastal or sedimentary environments and wastewater bioreactors. While extremely well studied in regards to their macronutrient cycling, ODZ-representative cultured organisms such as denitrifiers, ammoniaoxidizing archaea and bacteria (AOAs and AOBs), have not to our knowledge been rigorously examined in regards to their trace metal content. Vogel and Fisher (2010) investigated uptake and utilization rates of $\mathrm{Fe}, \mathrm{Mn}, \mathrm{Cd}$, and $\mathrm{Zn}$, among other elements, in five bacterioplankton species in surface seawater cultures and found that bacterial accumulation of Fe may be significant in the surface ocean. Other pTM-prokaryote associations have been reported for $\mathrm{Fe}$ (Tortell et al. 1996; Sunda and Huntsman 1997; Schmidt and Hutchins 1999), $\mathrm{Cu}$, and $\mathrm{Pb}$ (Dixon et al. 2006; Rossi and
Jamet 2008), Cd and Zn (Sunda and Huntsman 1995; Binet et al. 2003; Iyer et al. 2005), Mn (Francis et al. 2001), and V and Ni (Shirdam et al. 2006), though only a few examined prokaryotic strains relevant to the open ocean or ODZs. With prokaryotic biomass accounting for potentially half of oceanic POM (Cho and Azam 1988; Fuhrman et al. 1989) and despite these organisms' crucial global biogeochemical roles, there remains a surprising dearth of information on prokaryotic metal utilization in natural marine environments.

Redox-active trace metals, many of which are ultimately delivered to sediments via settling organic matter, also have importance as sedimentary paleotracers. Bioactive pTMs have been used to record the past extent of ODZs via sedimentary deposition of $\mathrm{Ba}, \mathrm{Cu}$, and $\mathrm{Cd}$ (Tribovillard et al. 2006). Sedimentary redox state, which can be influenced by ODZ extent due to its impingement along the shelf, is thought to control sedimentary retention of the paleoredox tracers Mo, Re, U, and V (Nameroff et al. 2004). Tribovillard et al. (2006) indicated that $\mathrm{Ni}$ and $\mathrm{Cu}$ may be paleoproxies for periods of high organic carbon delivery to sediments, as these pTMs can be preserved within authigenic sedimentary sulfides. In an extensive sediment core survey beneath the ETSP ODZ, Böning et al. (2004) indicated a biotic source, presumed to be the overlying euphotic zone, for $\mathrm{Cd}, \mathrm{Cu}, \mathrm{Ni}$, $\mathrm{Zn}$, and other pTMs that have delivery rates dominated by the downward vertical flux of organic matter. Metal stoichiometries and bulk TM associations for local biomass, including eukaryotic phytoplankton and ODZ prokaryotes, are thus relevant to interpretation of sedimentary paleoproxies, in addition to understanding the communities themselves.

Here we report pTM enrichments found in bulk particles associated with heterotrophic and autotrophic prokaryotic communities of the ETSP ODZ, sampled during the US GEOTRACES Eastern Pacific Zonal Transect (EPZT) in Oct-Dec 2013 (Fig. 1). The pTM composition of these communities is often significantly different, and pTM-enriched, compared to mixed layer communities. Prokaryotic biomass associated with the ODZ may influence the marine cycles and sedimentary imprint of trace metals in the ETSP and other oxygendeficient regions.

\section{Materials and methods}

\section{Sample collection, analyses, and data access}

All particulate samples were collected on the US GEOTRACES EPZT cruise GP16 from Lima, Peru to Tahiti in Oct-Dec 2013 (Fig. 1). Seawater was collected with the non-contaminating GEOTRACES rosette and filtered onto acid-cleaned, 25-mm diameter, $0.45 \mu \mathrm{m}$ pore-size Supor ${ }^{\mathrm{TM}}$ (polyethersulfone) filters in the GEOTRACES sampling van (Cutter et al. 2010; Planquette and Sherrell 2012). Typical filtration volumes through the analyzed filter halves were $4.4 \mathrm{~L} \pm 1.4 \mathrm{~L}$ seawater (median \pm one $\mathrm{SD}$ ). Digestion and analytical 


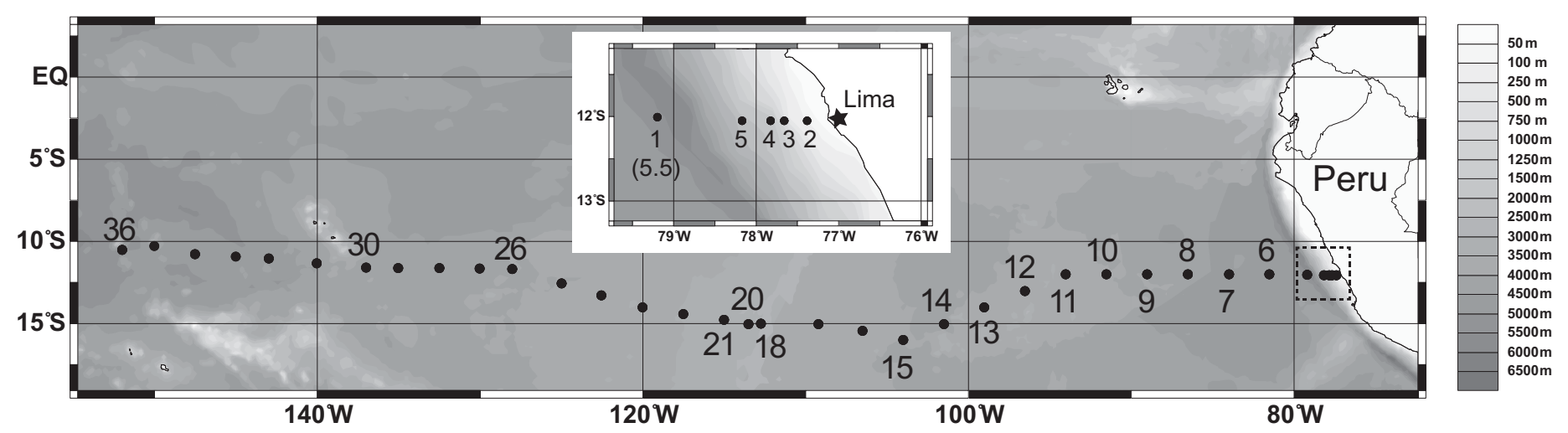

Fig. 1. Key stations from $R / V$ Thompson cruise TT303 (US GEOTRACES Eastern Pacific Zonal Transect GP16; Oct-Dec 2013), including all stations directly referenced in the text. Inset: "shelf" stations near the Peruvian coast, including Sta. 1 which is plotted as Sta. 5.5 in all other figures for longitudinal consistency. Sta. 6-13 are "ODZ" stations; Sta. 14-36 "gyre" stations. Shading indicates bathymetry.

procedures were as previously reported by our laboratory (Twining et al. 2015). Briefly, in a land-based analytical clean lab, filters were halved, digested in a mixture of $4 \mathrm{~mol}$ $\mathrm{L}^{-1}$ each $\mathrm{HCl} / \mathrm{HNO}_{3} / \mathrm{HF}$ optima-grade acids at $110^{\circ} \mathrm{C}$ in sealed Teflon vials, dried, and brought up in $0.32 \mathrm{~mol} \mathrm{~L}^{-1}$ $\mathrm{HNO}_{3}$ for analysis via ICP-MS (Thermo Element2). External multi-elemental standard curves and internal spikes of In (for ICP-MS instrumental drift) and Cs (for sample recovery purposes) were used to standardize and monitor elemental recoveries. Recoveries of the certified reference materials (CRMs) PACS-2 (marine sediment) and BCR-414 (plankton) and multi-elemental standard addition spikes into random samples were also used to monitor reported values. Recoveries of CRMs averaged $95 \% \pm 8 \%$ for PACS- 2 and $102 \% \pm$ $7 \%$ for BCR-414 across all elements. Full CRM recoveries, blank information, and methodological information including the details of hydrothermal sample analyses and laboratory intercalibration within the particle dataset, are available in the dataset metadata available via the NSF data archive at the Biological \& Chemical Oceanography Data Management Office (BCO-DMO), dataset \#639857.

Samples analyzed for acid-volatile sulfides (AVS) were collected using in situ pumps (McLane) suspended from a trace metal wire (Hytrel-jacketed Vectran), at the same stations and target depths as the GEOTRACES carousel, further described in Ohnemus and Lam (2015). Pumps filtered for

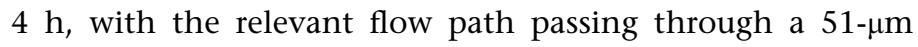
polyester pre-filter, then through paired $0.8-\mu \mathrm{m}$ pore-size, $142-\mathrm{mm}$ Supor ${ }^{\mathrm{TM}}$ polyethersulfone filters. A small portion of the top Supor filter, representing $\sim 2 \%$ of the filter area $(0.8-$ $51-\mu \mathrm{m}$ size-fraction material), was sub-sectioned into polyethylene vials and frozen at $-85^{\circ} \mathrm{C}$ until shipboard AVS analysis, described below. Filter blanks were held within identical filter housings and submerged on one of the deeper pumps on each cast but were not actively filtered through. Blanks were handled identically to samples during processing, which was conducted in a HEPA-filtered environment using trace metal clean procedures. The slight pore-size mismatch between pump-collected AVS samples and bottlefiltered pTMs ( $0.8 \mu \mathrm{m}$ vs. $0.45 \mu \mathrm{m}$ cutoff, respectively) is not expected to influence our results significantly, as used here. AVS data are available through the NSF data archive at BCODMO, dataset \#646143.

\section{Acid-volatile sulfide determination}

Determinations of acid-volatile sulfide (AVS) were made onboard ship and used the method of Cutter and Oatts (1987) that includes acidification, gas stripping, and cryogenic trapping/preconcentration of the generated hydrogen sulfide. In this case, the filter slice was placed in a glass stripping vessel, $10 \mathrm{~mL}$ of deionized water added, and the stripper purged with He. The cryogenic trap was then immersed in liquid nitrogen, $10 \mathrm{~mL}$ of $1 \mathrm{~mol} \mathrm{~L}^{-1} \mathrm{HCl}$ added through a septum in the stripping vessel and the evolved and trapped hydrogen sulfide was then quantified using the gas chromatography/flame photometric detection method of Radford-Knoery and Cutter (1993). The system was calibrated with hydrogen sulfide from a permeation tube (calibrated diffusion rate) and assuming a filtration volume of at least 5 liter (median sample volume: 7.9 liter), the detection limit was $0.2 \mathrm{pmol} / \mathrm{L}$. It should be noted that AVS determined by this method includes monosulfides of $\mathrm{Fe}, \mathrm{Zn}$, and $\mathrm{Ni}$, but not those with $\mathrm{Cu}$ or $\mathrm{Hg}$, or mixed oxidation state sulfides such as greigite or pyrite (Cutter and Oatts 1987; Radford-Knoery and Cutter 1993).

\section{Profiling CTD data}

Reported values for transmissometer voltage (WET Labs, $25-\mathrm{cm}$ path length, $660 \mathrm{~nm}$ ), fluorescence (Seapoint), and oxygen (Seabird SBE 43) were collected via the GEOTRACES carousel Seacat 9+ (Seabird) CTD after $1 \mathrm{~m}$ binning of higher-frequency profiling data; upcast traces are used herein, except when otherwise noted. Station occupations were often longer than $24 \mathrm{~h}$ and consisted of multiple casts on three sampling systems (GEOTRACES carousel, McLane pumps, and Oceanographic Data Facility [ODF] rosette) each 
equipped with a profiling CTD. We calculated median mixed layer depths across all profiling downcasts (using a 0.125 sigma-theta density change from the surface [Bishop and Wood 2009]) as well as median depths for the primary deep chlorophyll maximum (DCM) and 10\% fluorescence depths (the "particle production zone" or PPZ [Marra et al. 2014; Owens et al. 2015]). These values are reported in Table 1, along with the cast-specific ODZ start depth (upcast, defined and discussed below; Sta. 1-13) or depth of the local oxygen minimum (Sta. 14-36) from the cast on which ODZ bottle particle samples were taken.

\section{Use of oxygen saturation and ODZ/oxycline definitions}

We use oxygen saturation expressed as percent, rather than absolute oxygen concentrations, to examine the oxygen sensitivities and distribution patterns within this dataset. Our rationale is twofold and derives from our desire to best utilize the high-resolution oxygen data collected from a moving sensor (CTD-mounted Seabird SBE 43). First, the oxygen gradients of greatest interest-in the upper $10-30 \mathrm{~m}$ of the ODZ-are often very steep and narrow. The myriad biotic processes occurring in this region are known to be highly sensitive to nanomolar-level oxygen concentrations, so even slight instrumental hysteresis or response-time lag could lead to oxygen profiles that are offset from reality. We also noted a dataset-wide offset of $\approx+7 \mu \mathrm{M}$ in the SBE 43 sensor calibration, which was the mean oxygen concentration reported by the sensor within the ODZ. We have subtracted this offset given that oxygen concentrations in the ODZ have been shown by more sensitive switchable trace oxygen (STOX) sensors to be functionally nil $(<1-10 \mathrm{nM})$ throughout the region (Tiano et al. 2014). Our use of oxygen saturation in percent purposefully avoids over-interpretation of the absolute oxygen concentrations reported at the lowerend of our sensor's capabilities. Secondly, surface mixed layer temperatures, and thus oxygen saturation values, varied widely across the $>8000 \mathrm{~km}$ cruise track (Fig. 2A). Surface features from a wide range of mixed layer temperatures can be conveniently coalesced into a narrower range of near-saturation values (i.e., 95-110\%) by using oxygen saturation rather than absolute oxygen concentration.

Oxygen saturation was calculated using the equations of Benson and Krause (1984) and the 1-m-binned GEOTRACES carousel SBE 43 oxygen sensor values. Future versions of the cruise dataset may correct the reported sensor concentrations to better align with ODF carousel Winkler oxygen titrations, which report oxygen concentrations below the method's detection limit within the ODZ $(\leq \approx 3 \mu \mathrm{M})$.

We determined the upper boundary of the ODZ at each station using the first sustained appearance of curvature in the raw (uncorrected) SBE 43 oxygen sensor data on the upcast during which ODZ particulate samples were collected. This determination was guided, in part, by where the downcast trace indicated oxygen approaches zero. Our definition of the ODZ minimizes temporal separation from bottle sample collection and obviates uncertainty due to sensor hysteresis (vertical lag before reading zero) evident in the downcast data through the same depths. It is also consistent with the results of Tiano et al. (2014) who demonstrated that oxygen sensors are more stable on the upcast, and that ODZ-associated secondary fluorescence maxima typically exhibit $\leq 0.4$ $\mu \mathrm{M}$ oxygen which, by our definition, fall almost entirely within the ODZ. The region above the ODZ where oxygen increases towards the surface is referred to as the upper oxycline (up to $90 \%$ oxygen saturation); the increase in oxygen with depth below the ODZ will be referred to as the lower oxycline. We lack the sensor capability to directly differentiate the oxic-suboxic ODZ transition zone (where aerobic respiration can occur at the top of the ODZ) from the functionally anoxic ODZ core (where anaerobic respirations dominate). We do, however, use the appearance of fluorescence in the upper ODZ of many stations to delineate autotrophic (fluorescent) ODZ samples from heterotrophic (nonfluorescent) ODZ bottle samples.

\section{Background correction for vertically sourced particles in Table 3}

All ODZ particulate element maxima are present among some background of particles sourced from the overlying euphotic zone and oxycline, each likely with distinct remineralization rates and behaviors across the elemental suite. To isolate ODZ biomass elemental signals from particles sourced vertically above the ODZ, specifically for the Sta. 1113 stoichiometries reported in Table 3, a means to constrain the profile background was needed. We used a simple linear approach: at each station, reference depths above and below the ODZ were chosen for each elemental profile. A linear fit between the reference depths was used as a baseline in each profile, which was then subtracted from the local ODZ maxima. These values are referred to as "background-corrected."

\section{Pigment analyses}

Phytoplankton pigment concentrations were collected from the surface mixed layer and analyzed via HPLC at the University of Hawai'i. Pigments have been grouped according to broad size/function categories-microplankton, nanoplankton, and picoplankton-following Hooker et al. (2005).

\section{Results and discussion}

\section{Mixed layer biogeography}

The US GEOTRACES EPZT cruise comprised 36 stations across more than $8000 \mathrm{~km}$ of the ETSP (Fig. 1). The surface transect spanned large biogeochemical gradients associated with boundary and equatorial upwelling, so key surface mixed layer characteristics (Fig. 2) were used to group stations into three regions. The "Shelf ODZ" Sta. 1-5 (with Sta. 1 plotted as Sta. 5.5 in most figures, based on its longitude) overlie the Peruvian shelf and shelf break. These stations 
Table 1. Left four columns: median depth in meters, across all profiling casts at each station, for the surface mixed layer ( $\Delta \sigma_{\Theta}$ from surface $=0.125$ ), primary deep chlorophyll maximum, particle production zone (depth where $10 \%$ of primary DCM fluorescence remains), and minimum oxygen concentration (Sta. 14-36 only). Right two columns: on the cast when ODZ bottle particles were collected: ODZ start depth (described in methods), and thickness of the upper oxycline (calculated as the ODZ start depth minus ML depth).

\begin{tabular}{|c|c|c|c|c|c|c|c|}
\hline \multirow[b]{2}{*}{ Stations } & & $\begin{array}{c}\text { Mixed layer } \\
\text { depth } \\
\left(\Delta \sigma_{\Theta}=0.125\right)\end{array}$ & $\begin{array}{l}\text { Primary deep } \\
\text { chlorophyll } \\
\text { max (DCM) } \\
\text { depth }\end{array}$ & $\begin{array}{c}\text { Particle } \\
\text { production } \\
\text { zone depth }\end{array}$ & $\begin{array}{c}\text { Oxygen } \\
\text { minimum depth }\end{array}$ & $\begin{array}{c}\text { ODZ Start } \\
\text { depth }\end{array}$ & $\begin{array}{c}\text { Upper oxycline } \\
\text { thickness }\end{array}$ \\
\hline & & \multicolumn{6}{|c|}{ All depths and thicknesses in $\mathrm{m}$} \\
\hline Shelf ODZ & $1(5.5)$ & 46 & 34 & 66 & & 84 & 37 \\
\hline \multirow[t]{4}{*}{ stations } & 2 & 8 & 6 & 30 & & 59 & 51 \\
\hline & 3 & 8 & 6 & 25 & & 35 & 27 \\
\hline & 4 & 16 & 9 & 43 & & 50 & 34 \\
\hline & 5 & 25 & 20 & 50 & & 59 & 33 \\
\hline Offshore & 6 & 31 & 38 & 80 & & 100 & 69 \\
\hline \multirow[t]{7}{*}{ ODZ stations } & 7 & 50 & 36 & 94 & & 98 & 48 \\
\hline & 8 & 46 & 53 & 105 & & 114 & 67 \\
\hline & 9 & 53 & 53 & 109 & & 111 & 58 \\
\hline & 10 & 78 & 60 & 121 & & 153 & 75 \\
\hline & 11 & 51 & 55 & 130 & & 190 & 140 \\
\hline & 12 & 41 & 47 & 124 & & 215 & 174 \\
\hline & 13 & 78 & 62 & 139 & & 231 & 153 \\
\hline \multirow[t]{23}{*}{ Gyre stations } & 14 & 89 & 75 & 164 & 322 & & \\
\hline & 15 & 74 & 82 & 168 & 375 & & \\
\hline & 16 & 56 & 59 & 150 & 365 & & \\
\hline & 17 & 57 & 59 & 163 & 372 & & \\
\hline & 18 & 36 & 69 & 174 & 359 & & \\
\hline & $19^{*}$ & 30 & 72 & 174 & 362 & & \\
\hline & 20 & 49 & 62 & 191 & 393 & & \\
\hline & 21 & 59 & 74 & 167 & 373 & & \\
\hline & 22 & 56 & 82 & 179 & 376 & & \\
\hline & 23 & 45 & 74 & 169 & 350 & & \\
\hline & 24 & 54 & 68 & 163 & 359 & & \\
\hline & 25 & 76 & 92 & 163 & 350 & & \\
\hline & 26 & 57 & 84 & 169 & 334 & & \\
\hline & 27 & 60 & 65 & 184 & 320 & & \\
\hline & 28 & 67 & 78 & 162 & 343 & & \\
\hline & 29 & 66 & 74 & 175 & 351 & & \\
\hline & 30 & 74 & 81 & 168 & 347 & & \\
\hline & 31 & 65 & 67 & 146 & 337 & & \\
\hline & 32 & 84 & 84 & 153 & 335 & & \\
\hline & 33 & 65 & 84 & 186 & 336 & & \\
\hline & 34 & 58 & 52 & 175 & 310 & & \\
\hline & 35 & 67 & 57 & 170 & 328 & & \\
\hline & 36 & 60 & 74 & 179 & 376 & & \\
\hline
\end{tabular}

*Data from ODF carousel only.

were characterized by comparatively cool, nutrient-rich, upwelling-influenced water (surface $T=13.9-17.4^{\circ} \mathrm{C} ; \mathrm{PO}_{4}>1$ $\left.\mu \mathrm{M} ; \mathrm{NO}_{3}>7.5 \mu \mathrm{M}\right)$, shallow mixed layer depths (8-46 m vs.
30-89 m elsewhere), macroplankton pigment dominance (diatoms and dinoflagellates), and strong particle (transmissometer) and particulate P enrichments (particulate P: 169- 

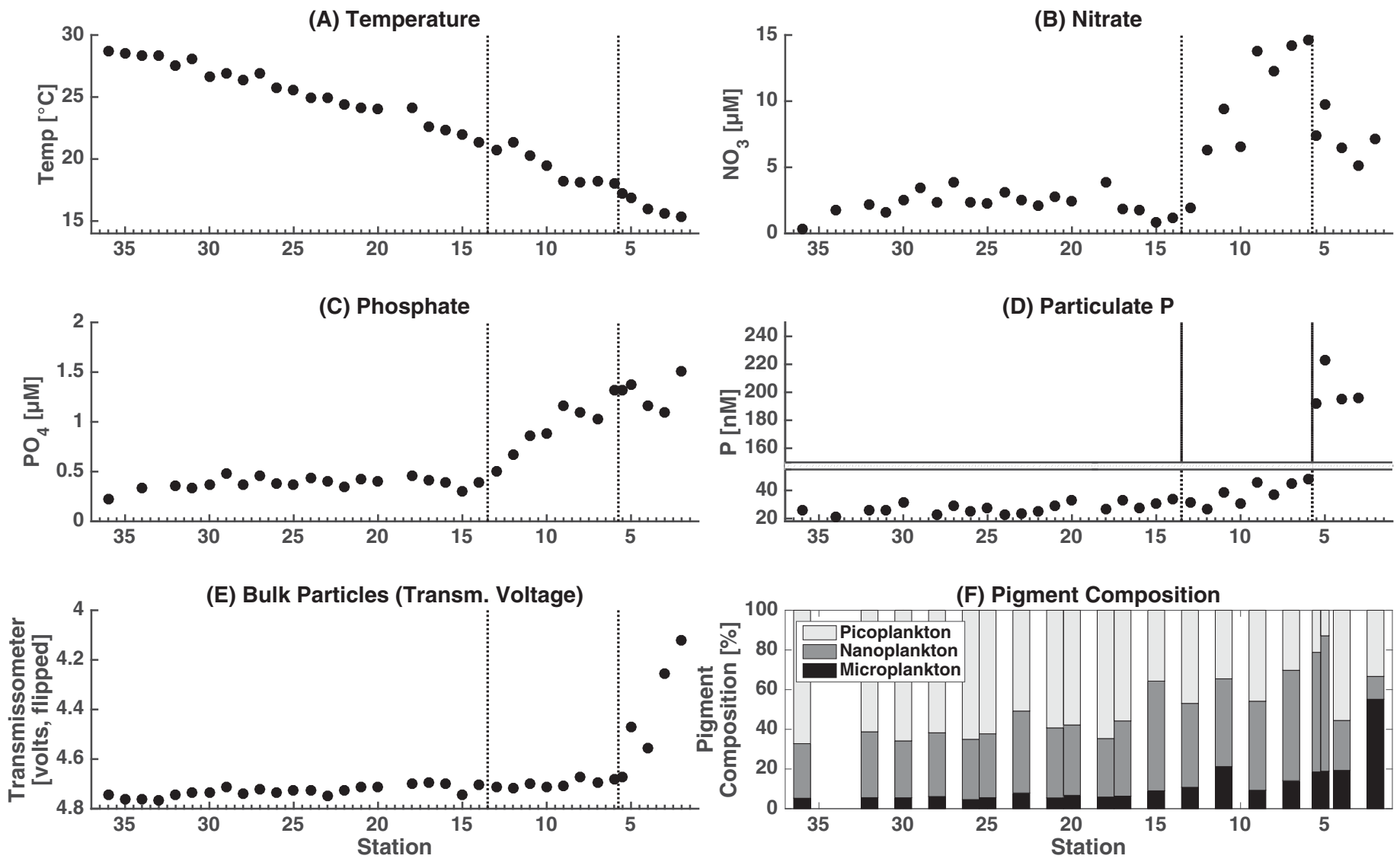

Fig. 2. Key surface mixed layer parameters ( $y$-axes) from west to east across the transect (station number on $x$-axes, in reverse scale for longitudinal consistency): (A) temperature, (B) nitrate, (C) phosphate, (D) particulate P, (E) bulk particle concentration (via transmissometer voltage), (F) bulk pigment fractionation. Median values are plotted in panel A-E, and Sta. 1 is plotted as Sta. 5.5 for longitudinal consistency. Vertical dotted lines separate the three station groupings, from right to left (east to west): shelf Sta. 1-5 (cool, nutrient-rich water; high particle loads, elevated macroplankton concentrations); ODZ Sta. 6-13 (lower particulate P; declining nutrients; lower particle loads, mixed nano/picoplankton dominance); gyre stations $\geq 14$ (lowest particulate $\mathrm{P}$ and nutrients; warmest temperatures, picoplankton dominance).

$235 \mathrm{nM})$. In contrast, “Offshore ODZ” Sta. 6-13 were characterized by an ecosystem shift to smaller nanoplankton cells, coincident with rising temperatures $\left(18-23^{\circ} \mathrm{C}\right)$, declining $\mathrm{PO}_{4}(0.5-1.5 \mu \mathrm{M})$ and $\mathrm{NO}_{3}(0.8-14.7 \mu \mathrm{M})$, and significantly lower particulate $\mathrm{P}(25.6-45.6 \mathrm{nM})$. The "gyre" Sta. 14-36 were picoplankton-dominated, exhibiting the warmest surface temperatures $\left(22.7-29.1^{\circ} \mathrm{C}\right)$ and the lowest and most narrowly constrained concentrations of particulate $\mathrm{P}(21.7-32.0 \mathrm{nM}), \mathrm{PO}_{4}(0.20-0.47 \mu \mathrm{M})$, and $\mathrm{NO}_{3}(0.3-3.9 \mu \mathrm{M})$.

\section{Hydrography}

Upper waters of the shelf stations are influenced by Equatorial Subsurface Waters (ESSW) moving poleward in the ODZ via the Peru-Chile Undercurrent, while the offshore ODZ stations are dominated by Subantarctic Water (SAAW) moving equator-ward via the Humboldt Current (Silva et al. 2009; Llanillo et al. 2013). Offshore stations are dominated by Subtropical Surface Water (STSW) formed under the high evaporation in the gyre, moving poleward (Fiedler and Talley
2006). More detailed watermass analyses will be presented in forthcoming publications by other GEOTRACES GP16 cruise participants.

\section{Subsurface ODZ}

The subsurface ODZ was apparent in a suite of sensor and chemical data available from the GEOTRACES dataset (Fig. 3). As demonstrated by the section oxygen contour lines, all shelf and ODZ stations display strong oxygen consumption in an upper oxycline that begins near the base of the mixed layer. At Sta. 1-13, where oxygen approaches zero at the bottom of the upper oxycline, the appearance of dissolved nitrite, particulate $\mathrm{P}$, bulk particles (measured by transmissometry), a secondary deep fluorescence maximum (at Sta. 1-10), and loss of particulate Mn all indicate a transition into the ODZ, which is approximated in Fig. 3 sections by the $1 \%$ oxygen saturation contour. From east to west the ODZ start depth deepens from a minimum of $35 \mathrm{~m}$ at Sta. 3 to $231 \mathrm{~m}$ at Sta. 13, the westernmost station to achieve suboxic conditions (Table 1). This westward 
Table 2. Upper sections: Ratios used in lithogenic (left) and ferruginous (right) corrections. Upper and bulk continental crust ratios to Ti from (Taylor and McLennan 1995) and are compared to lithogenic-rich benthic nepheloid layer samples near South America (Sta. 3-9; $n=38$ samples). Values used in the lithogenic correction are bolded. For elements that lacked good correlation with Ti in eastern boundary nepheloid layers (italicized $r^{2}$ values), the larger of upper or bulk continental crust values was used, except for Mn where we use the lower, upper continental crust value to avoid over-correction of a potential carrier phase (Mn oxyhydroxides). Ferruginous corrections are based on metal:Fe ratios in Fe-oxyhydroxide-rich particles sampled near the East Pacific Rise hydrothermal plume at Sta. 18, 2450-2550 m ( $n=10$ samples). Lower sections: median lithogenic (left) and ferruginous (right) corrections (percent of pTM concentration subtracted \pm 1 SD) in the mixed layer and ODZ depth regions. Ferruginous corrections are shown for ODZ samples only, as lithogenic corrections can account for nearly all Fe in mixed layer samples.

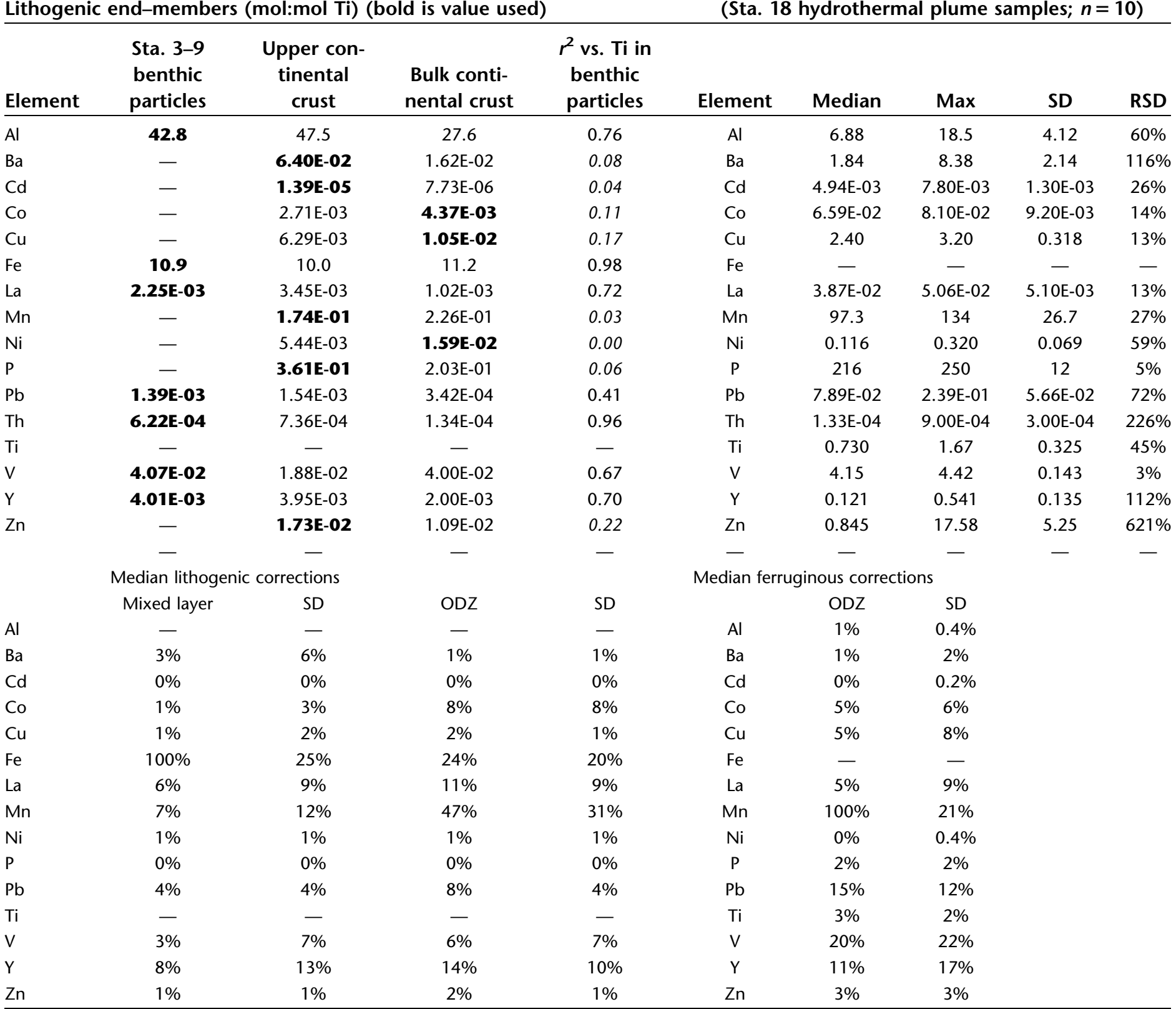

deepening of the ODZ corresponds to a thickening of the upper oxycline and a deepening of the "particle production zone" (the depth where $10 \%$ of primary DCM fluores- cence remains [Marra et al. 2014]): the upper oxycline is only $27-\mathrm{m}$ thick at Sta. 3 but more than $150-\mathrm{m}$ thick at Sta. 12 and 13. 
Table 3. $P$ concentrations (nM) and element: $P$ stoichiometries (mmol:mol) for several station groupings, comparing mixed layer $(\mathrm{ML})$ and $\mathrm{ODZ}$ values (median $\pm \mathrm{SD}$ ). All values are after lithogenic and ferruginous corrections. Station-by-station data are shown in graphical form in Fig. 8. Station groupings: Sta. 1-5 (shelf ODZ), 6-10 (autotrophic offshore ODZ), and 11-13 (heterotrophic offshore ODZ). Bold: ODZ stoichiometries that differ significantly from $\mathrm{ML}$ in the same region ( $t$-test, $p<0.05)$. For Sta. 11-13, background-corrected (ODZ local maxima) P concentrations and heterotrophic stoichiometries are also provided. Right four columns: ratio of median ODZ/ML stoichiometry for each region.

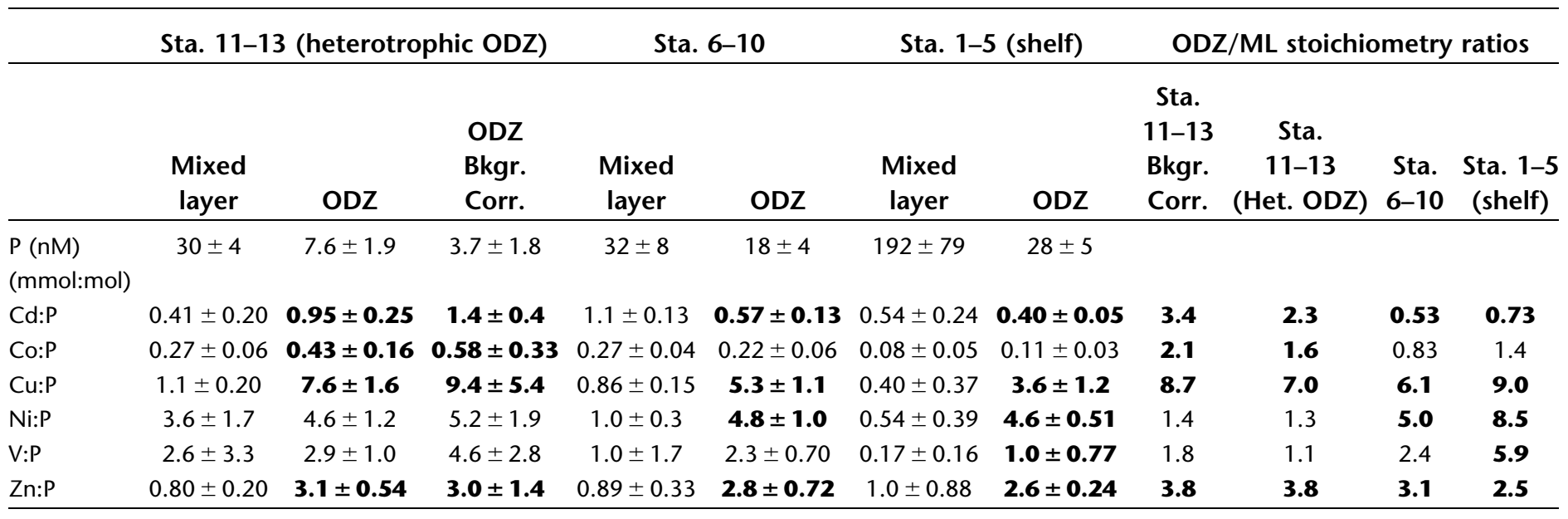

\section{Particulate $P$ maxima in the $O D Z$}

Initial observations of the particulate dataset indicated significant subsurface maxima in particulate $P$ at low oxygen that were distinct from surface mixed layer maxima and suggested in situ production of biogenic material within the ODZ. Particulate P concentrations from the upper $400 \mathrm{~m}$ of offshore ODZ stations plotted vs. depth (Fig. 4A) and oxygen saturation (Fig. 4B) exhibit three distinct particle regimes: a mixed layer $\mathrm{P}$ maximum associated with oxic mixed layer biomass; the upper oxycline, where $\mathrm{P}$ rapidly declines and where Mn oxyhydroxides appear (Figs. 3E, 4C,D); and a distinct, local $\mathrm{P}$ maximum associated with the ODZ. When plotted vs. depth, particulate $\mathrm{P}$ data collapse into a rather consistent "Martin curve" power law decay below the euphotic zone (Fig. 4B; $b$-value -1.07 , trendline not shown), but concentrations of $\mathrm{P}$ in ODZ samples are distinctly enriched.

The ODZ P maxima were coincident with near-complete, vertically sharp loss of particulate $\mathrm{Mn}$, which drops from typical oxycline concentrations of $100-300 \mathrm{pM}$ to $<100 \mathrm{pM}$ in the ODZ (median particulate Mn concentration in the ODZ: $17 \mathrm{pM}$ ). This distribution is consistent with Mn oxyhydroxides precipitated by Mn-oxidizing bacteria just beneath the mixed layer (Cowen and Bruland 1985) being reductively dissolved as they settle into the suboxic ODZ (Fig. 4C,D). In addition to particulate Mn minima, biological utilization of secondary electron acceptors beginning at or near the $1 \%$ saturation horizon indicated a distinct shift in water column redox state. Secondary nitrite maxima (Fig. 3A) and nitrate deficits (not shown) indicate that loss of fixed $\mathrm{N}$ is occurring within the ODZ.
The P maxima associated with the ODZ are not slight: even after correction for lithogenic phases (crustally derived, refractory particles) and ferruginous phases (authigenic $\mathrm{Fe}$ oxyhydroxides; Table 2, discussed later), ODZ P concentrations have $25 \%$ and $75 \%$ quartiles of $11 \mathrm{nM}$ and $26 \mathrm{nM}$, respectively, compared to $<5 \mathrm{nM}$ in similar depths of the oxic water column. Linear interpolation between points above and below the ODZ can be used to estimate P concentrations in excess of profile background concentrations. Local P maxima in the ODZ estimated in this manner range between $1 \mathrm{nM}$ and $17 \mathrm{nM}$. By comparison, surface mixed layer biomass at offshore stations ranges between $22 \mathrm{nM}$ and 46 nM P. Particulate Fe enrichments in the ODZ (shown relative to $\mathrm{Ti}$; local crustal value of $10.9 \mathrm{~mol}$ :mol indicated) are also apparent, especially in shelf-associated stations and in the upper ODZ at Sta. 6-9.

To allow side-by-side comparison of ODZ features across stations, parameters were plotted on a depth scale with the upper oxycline/ODZ boundary defined as $0 \mathrm{~m}$ (Fig. 5). For stations lacking an ODZ, west of Sta. 13 at $100^{\circ} \mathrm{W}$, the depth scale was set to zero at the oxygen minimum (Table 1). ODZ-associated secondary fluorescence maxima are notably confined to a depth range between $\approx 10 \mathrm{~m}$ above and $\approx 40 \mathrm{~m}$ below the ODZ start, and fluorescence is absent at westernmost ODZ Sta. 11-13. Particulate P and bulk particle (transmissometry) maxima generally coincide with one another and appear sharply constrained by the upper ODZ boundary, though we note that discrete bottle sampling did not always exactly align with transmissometry particle maxima. Particulate $\mathrm{P}$ and bulk particles notably extend more deeply into the ODZ than does fluorescence, suggesting a 

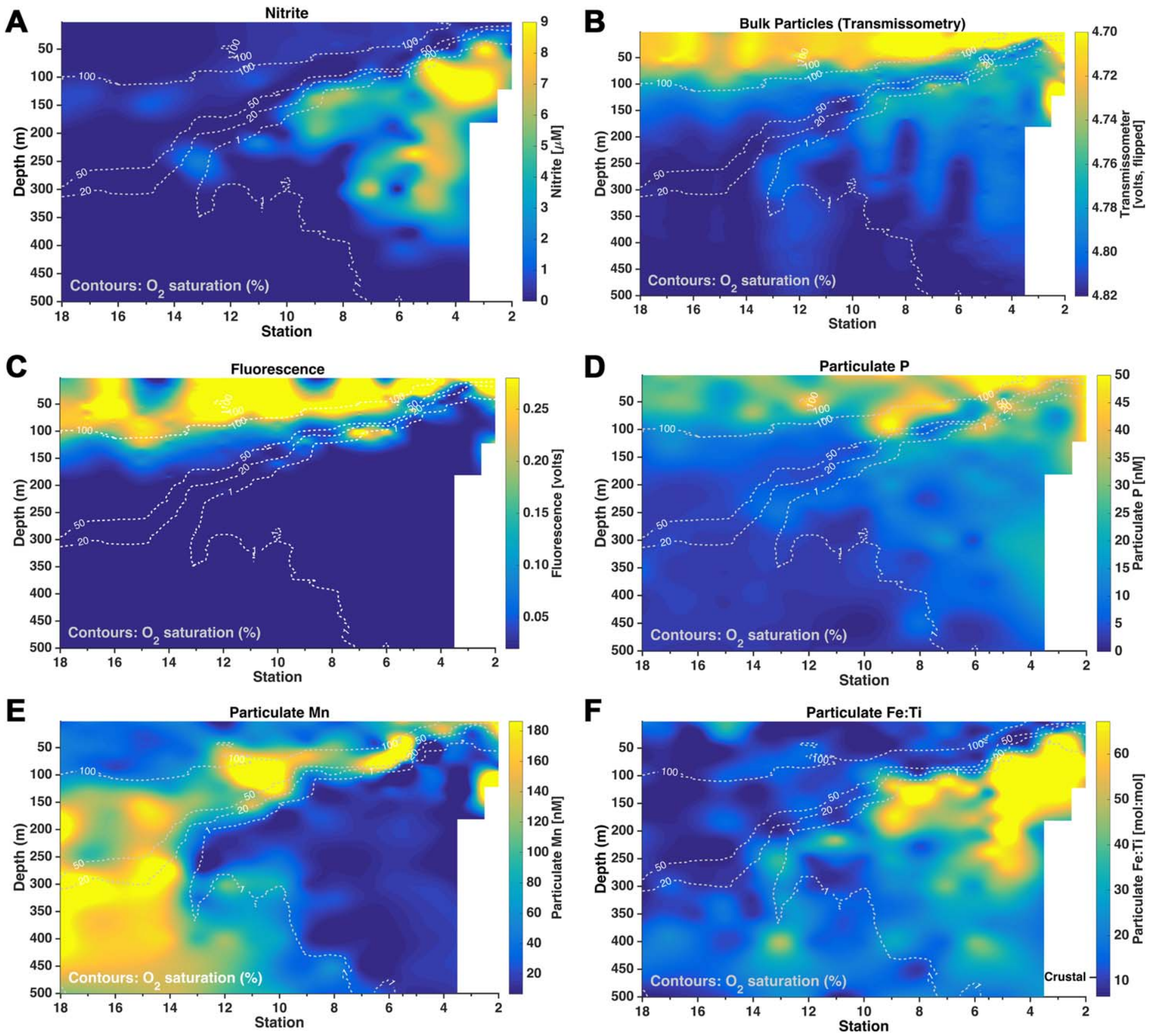

Fig. 3. Sections of $(\mathbf{A})$ nitrite, $(\mathbf{B})$ particulate $P,(\mathbf{C})$ bulk particles (transmissometer voltage), (D) fluorescence, (E) particulate Mn, and (F) particulate $\mathrm{Fe}: \mathrm{Ti}$, overlaid by contours of oxygen saturation (\%; dashed lines and labels) between gyre Sta. 18 in the west and shelf Sta. 2 in the east. Sta. 1 is plotted as Sta. 5.5 for longitudinal consistency. Horizontal scale (station number) allows visual comparison of shelf to offshore stations and is not meant to approximate true spatial distance, though offshore stations west of Sta. 6 are evenly spaced (Fig. 1). The oxycline/ODZ boundary is approximated by the $1 \%$ oxygen saturation contour.

shift from autotrophic to heterotrophic biomass as depth within the ODZ increases.

Secondary fluorescence maxima found in the upper ODZ at Sta. 1-10 are likely associated with the pigments of lowlight adapted Prochlorococcus (Goericke et al. 2000; Lavin et al. 2010) and perhaps anoxygenic photosynthetic prokaryotes (Repeta et al. 1989; Béjà et al. 2002; Allgaier et al.
2003) that are known to inhabit these low-predation, lowlight niches. Secondary fluorescence maxima are notably absent at the westernmost stations with the deepest ODZs (Sta. 11-13), perhaps indicating insufficient light for autotrophic processes (though photosynthetically active radiation [PAR] was not measured on the CTD). The absence of fluorescence yet continued appearance of local P maxima at Sta. 

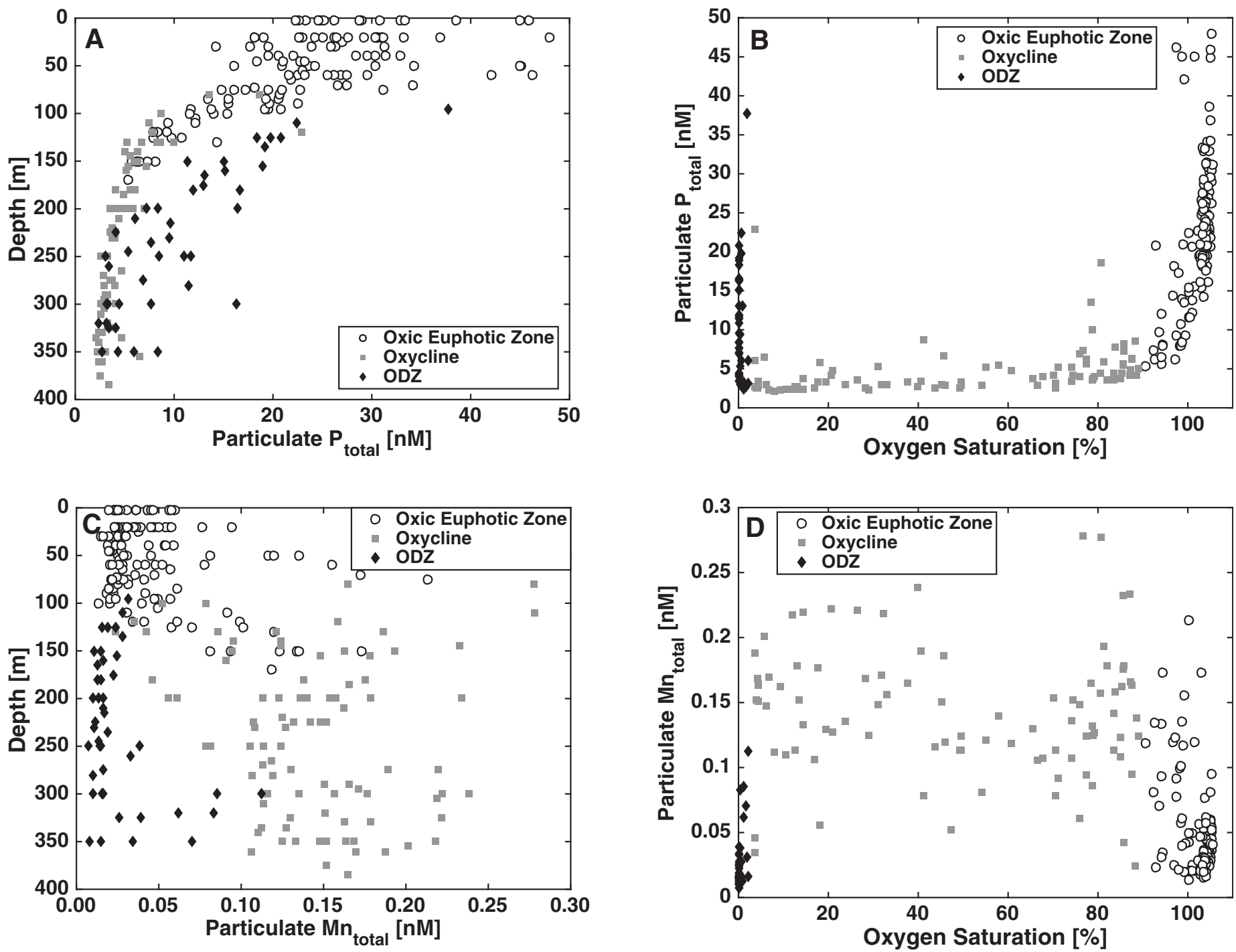

Fig. 4. Particulate $P$ in the upper $400 \mathrm{~m}$ of $O D Z$ and gyre stations (stations $\geq 6$ ) plotted (A) vs. depth, and (B) vs. sample oxygen saturation. For clarity, only samples with $\leq 50 \mathrm{nM}$ particulate $\mathrm{P}$ are shown. In panel A, shallow $(2 \mathrm{~m})$ towed-fish surface samples that lack paired oxygen data are plotted at $105 \%$ oxygen saturation. Sample shading and shape indicate general oxygen state: white circles: oxic euphotic zone samples with oxygen saturation $\geq 90 \%$; gray squares: upper oxycline (oxygen saturation between $1 \%$ and $90 \%$ ); black diamonds: ODZ (oxygen saturation $<1 \%$ ). (C, D) Same as A and B, but for particulate Mn.

11-13 suggest the presence of completely heterotrophic communities in these ODZs, where different (typically enriched) trace metal stoichiometries were also observed (see Particulate trace metals ( $p T M s$ ) in the ODZ section).

An especially clear indicator of the oxygen sensitivity of the deeper ODZ particle assemblages occurred at Sta. 8 where two maxima in bulk particles (transmissometry) were observed (Fig. 5D). A steep drop in particles at $\approx 50 \mathrm{~m}$ into the ODZ was associated with the appearance of a local oxygen maximum there, a phenomenon also occasionally observed in drifter transects of the region (Whitmire et al. 2009). Particle load increases again below this oxygen signal, once oxygen has dropped to negligible values. Despite the capability for many upper ODZ organisms to rapidly switch between aerobic and anaerobic metabolisms (Tiano et al. 2014), disruptions to the anoxic environment deeper in the ODZ appear to be associated with strong, vertically rapid decreases in the local particle load. We take this result to indicate the strong oxygen sensitivity, and likely predominantly biotic nature, of much of the ODZ particle regime.

\section{Correction for lithogenic and ferruginous phases}

To isolate the elemental composition of biogenic phases from other particle types, we performed sequential corrections for lithogenic (crustally sourced) and ferruginous (in situ produced Fe-rich, e.g., Fe oxyhydroxide) phases. 

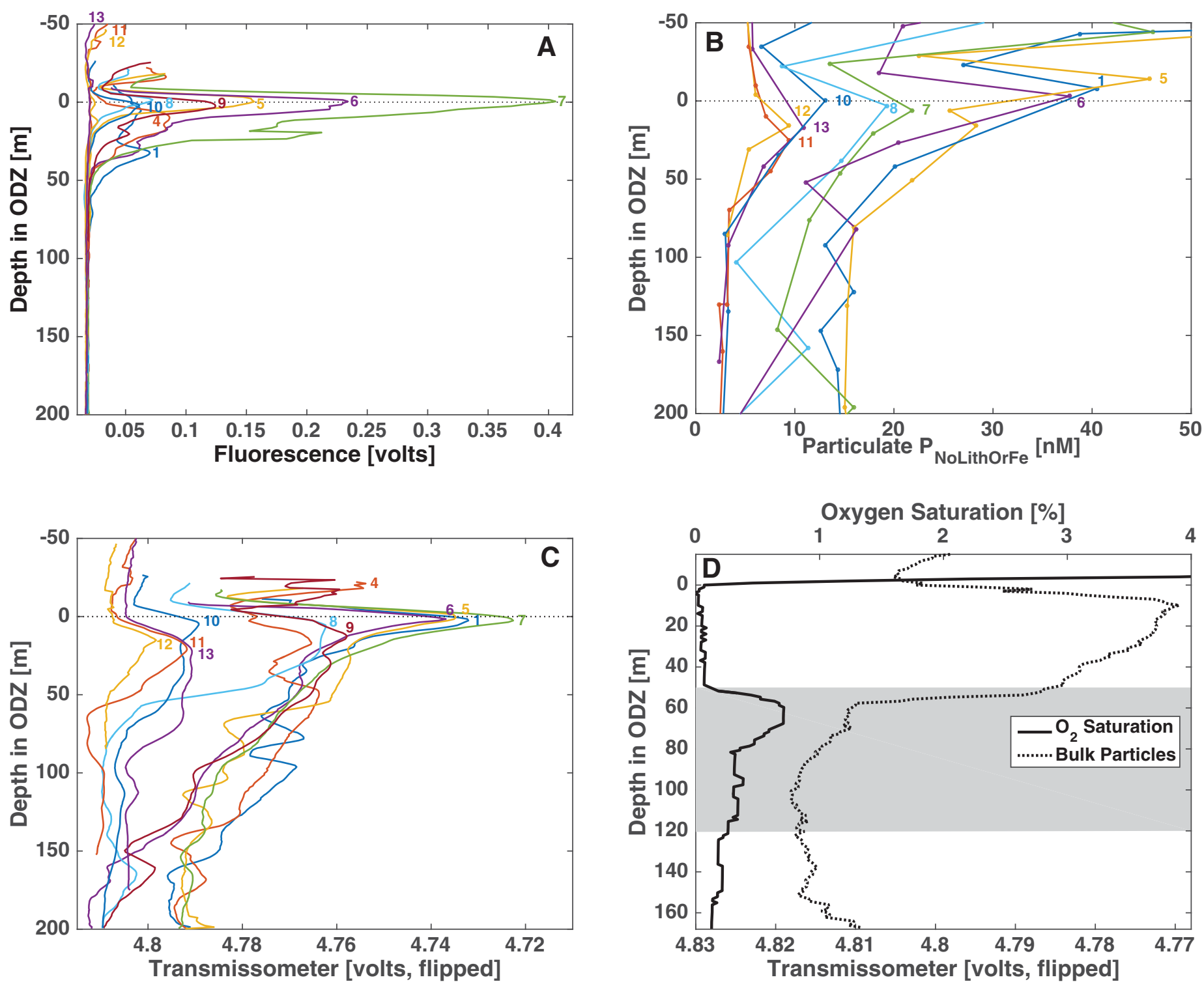

Fig. 5. Overlain profiles at Sta. 4 through 13 (colors, annotations) for (A) Chl- $a$ fluorescence, (B) particulate $P$ (after correction for lithogenic and Feoxides-see below), and (C) bulk particle concentration (transmissometer voltage), within the upper portion of the ODZ. Depth scale is relative to the upper boundary of the ODZ (dashed horizontal line). ODZ-associated secondary fluorescence maxima are generally confined to the upper $40 \mathrm{~m}$ of the ODZ and are absent at Sta. 11-13. ODZ P-maxima and bulk particle maxima (transmissometry) exhibit deeper penetration into the ODZ than fluorescence, especially at stations nearer shore. Profiles are truncated where oxygen rises above $40 \%$ oxygen saturation, to provide vertical context above the ODZ. (D) At Sta. 8 an intervening local oxygen maximum (gray shaded area) separates a shallower, intense particle maximum from a deeper, less intense particle maximum. A steep drop in particle abundance is seen at the upper edge of the oxygen maximum, while below, particles only increase again once oxygen has dropped.

\section{Lithogenic correction}

As lithogenic tracers, both particulate $\mathrm{Al}$ and Ti have merits (Ohnemus and Lam, 2015), with Al more consistent in abundance across crustal sources (typically $\approx 8 \%$ by weight) but having demonstrable in situ scavenging, while $\mathrm{Ti}$ is more variable across crustal sources but has lower scavenging potential. We opted to use $\mathrm{Ti}$ as a lithogenic tracer because we were able to estimate the composition of local lithogenic material using eastern margin (Sta. 1-9), near-bottom benthic nepheloid layer (BNL) samples. These samples showed the presence of resuspended BNLs via transmissometry and $\mathrm{Ti}$ and $\mathrm{Al}$ concentrations that were well correlated with many pTMs. The element:Ti lithogenic ratios in BNL particles are compared to prior estimates for upper and bulk continental crust in Table 2. Some bioactive metals with low crustal abundances exhibited poor correlations with $\mathrm{Al}$ and Ti. For these elements, except Mn, the larger of either the bulk or upper continental crustal ratio to Ti was used to 
provide a conservative (upper-bound) estimate of lithogenic contributions. For $\mathrm{Mn}$, we used the smaller, upper continental crust value to prevent over-correction of the authigenic Mn-oxyhydroxide carrier phase. This decision proved rather insignificant, however, as particulate $\mathrm{Mn}$ is already very low within the ODZ, even prior to lithogenic correction (Fig. 3, $\mathrm{Mn})$.

The transect region is notable for its extremely low aeolian dust inputs (Mahowald et al. 2008; Wagener et al. 2008); resultant lithogenic corrections were generally less than $8 \%$ for most bioactive TMs in mixed layer samples (Table 2). In the case of Fe, however, mixed layer abundances were low and variable enough to be statistically indistinguishable from lithogenic ratios to $\mathrm{Ti}$, except in the mixed layers of shelf Sta. 2-5 that retained $24-60 \%$ of their Fe after lithogenic correction. In the ODZ, lithogenic corrections for most bioactive elements were minimal, suggesting predominantly non-lithogenic particulate carrier phases there. A non-negligible portion $(24 \pm 20 \%)$ of the particulate Fe load within the ODZ, however, was found to be associated with lithogenic material. One possibility is that despite low regional aeolian lithogenic inputs, long residence times for fine lithogenic particles settling into the upper ODZ may allow for some refractory particle accumulation there (Ohnemus and Lam, 2015).

\section{Ferruginous correction}

Corrections for ferruginous phases in the ODZ are less constrained than for lithogenic phases, as less is known about the scavenging of a broad suite of trace metals in seawater by authigenically precipitating Fe phases. To address this, we examined two types of Fe-rich particulate samples: those found in association with the shelf ODZ stations (Fig. 3F, particulate Fe:Ti) and in the uniquely Fe-rich East Pacific Rise hydrothermal plume, where hydrothermal fluids rich in $\mathrm{Fe}^{2+}$ are rapidly oxidized and precipitate as Fe oxyhydroxides upon mixing with oxic seawater. These hydrothermal particles, along with a small fraction of dissolved $\mathrm{Fe}$, remain suspended during a decades-long transit thousands of kilometers to the west (Resing et al. 2015). At the sampling point nearest to the ridge axis, Sta. 18, the suspended plume was concentrated (lower and upper particulate Fe quartiles for $n=10$ plume samples were $48 \mathrm{nM}$ and $79 \mathrm{nM}$, respectively). Fe speciation in these samples was dominated by Fe(III) oxyhydroxides, while Fe sulfides were undetectable (Toner et al. 2014). In Fig. 6, we compare the particulate TM:Fe ratios in hydrothermal plume samples to those in $\mathrm{Fe}-$ rich shelf ODZ samples, the latter of which are best exemplified by the benthic nepheloid layer sample at Sta. 2 which had $130 \mathrm{nM}$ Fe. Ultimately, we use the particulate TM:Fe signature of hydrothermal plume particles to correct for the ferruginous end-member for the following reasons.

An important consideration is the potential for authigenic Fe phases to scavenge dissolved phosphate from seawater, potentially leading to erroneous interpretations of the presence of biomass. Importantly, however, we note that the scavenging of $\mathrm{P}$ by hydrothermal Fe oxyhydroxides yields only $\approx 0.2$ mol $\mathrm{P}$ per mole Fe precipitated, consistent with previous measurements at the EPR (0.17 mol:mol P/Fe) (Feely et al. 1998) and estimates of an upper limit of $0.5 \mathrm{~mol}$ $\mathrm{P}$ per mol Fe during $\mathrm{Fe}^{2+}$ precipitation in seawater (Gunnars and Blomqvist 1997; Gunnars et al. 2002; Senn et al. 2015). In the ODZ, ratios of $\mathrm{P} / \mathrm{Fe}$ in particles were much highermedian $9.3 \mathrm{~mol} \mathrm{P} / \mathrm{mol} \mathrm{Fe}$, ranging from 2.3 to $140 \mathrm{~mol}$ $\mathrm{P} / \mathrm{mol} \mathrm{Fe}$. This suggests the dominance of biogenic phases, not ferruginous phases, in carrying particulate $P$, even in shelf ODZ particles where the Fe content of particles was high.

Vanadium has an oxyanion-dominated speciation in seawater with a known affinity for positively charged Fe oxyhydroxide surfaces (Trefry and Metz 1989). Indicative of its potential to demonstrate Fe oxyhydroxide scavenging, ratios of $\mathrm{V}$ to $\mathrm{Fe}$ in Fe-rich shelf ODZ particles were similar to those in hydrothermal plume particles (Fig. 6, V), as were ratios of $\mathrm{Cu} / \mathrm{Fe}$ (Fig. 6, $\mathrm{Cu}$ ), $\mathrm{La} / \mathrm{Fe}$, and $\mathrm{Y} / \mathrm{Fe}$ (not shown). This suggests Fe-oxyhydroxide-dominated carrier phases for these elements in Fe-rich shelf ODZ samples, though corrections for these elements in the majority of ODZ samples, where Fe contents are lower, nevertheless remain rather moderate (medians corrections; Table 2).

Ratios of other pTMs to Fe in shelf ODZ samples were much higher than in plume particles (e.g., Fig. 6, Cd, P). This is potentially explained by the substantial concentrations of biomass (P) over the shelf, with more than $1000 \mathrm{nM}$ particulate P (vs. $130 \mathrm{nM} \mathrm{Fe}$ ) in the Sta. 2 BNL sample alone. The benthic/shelf sources of particulate Fe to shelf ODZ stations also apparently supply significant concentrations of biomass or biodetritus, which could be ultimately sourced from the overlying water column and/or the sediments. These inputs may also have undergone multiple sedimentation/resuspension cycles, further altering their composition. Given that the composition of this organic matter remains unknown, and that particulate P (biomass), not Fe, may be the dominant carrier phase for many pTMs, we based our ferruginous correction on the abiotically dominated hydrothermal plume particles. In doing so, we assume that all non-lithogenic Fe within the ODZ is composed of this ferruginous end-member, and correct the other pTMs using the median Sta. 18 pTM:Fe ratios (Ferruginous end-member; Table 2).

For most bioactive trace metals and $\mathrm{P}$, ferruginous corrections based on hydrothermal plume pTM:Fe ratios were small in the ODZ (typically less than 10\%; Table 2), with higher median corrections for $\mathrm{V}, \mathrm{Pb}$, and $\mathrm{Y}$. Already vanishingly low Mn concentrations in the ODZ can be completely accounted for by ferruginous phases. Elements corrected for both lithogenic and ferruginous phases $(\mathrm{Cd}, \mathrm{Co}, \mathrm{Cu}, \mathrm{Ni}, \mathrm{V}$, and $\mathrm{Zn}$ ) are referred to with the suffix "_NoLithOrFe," while 

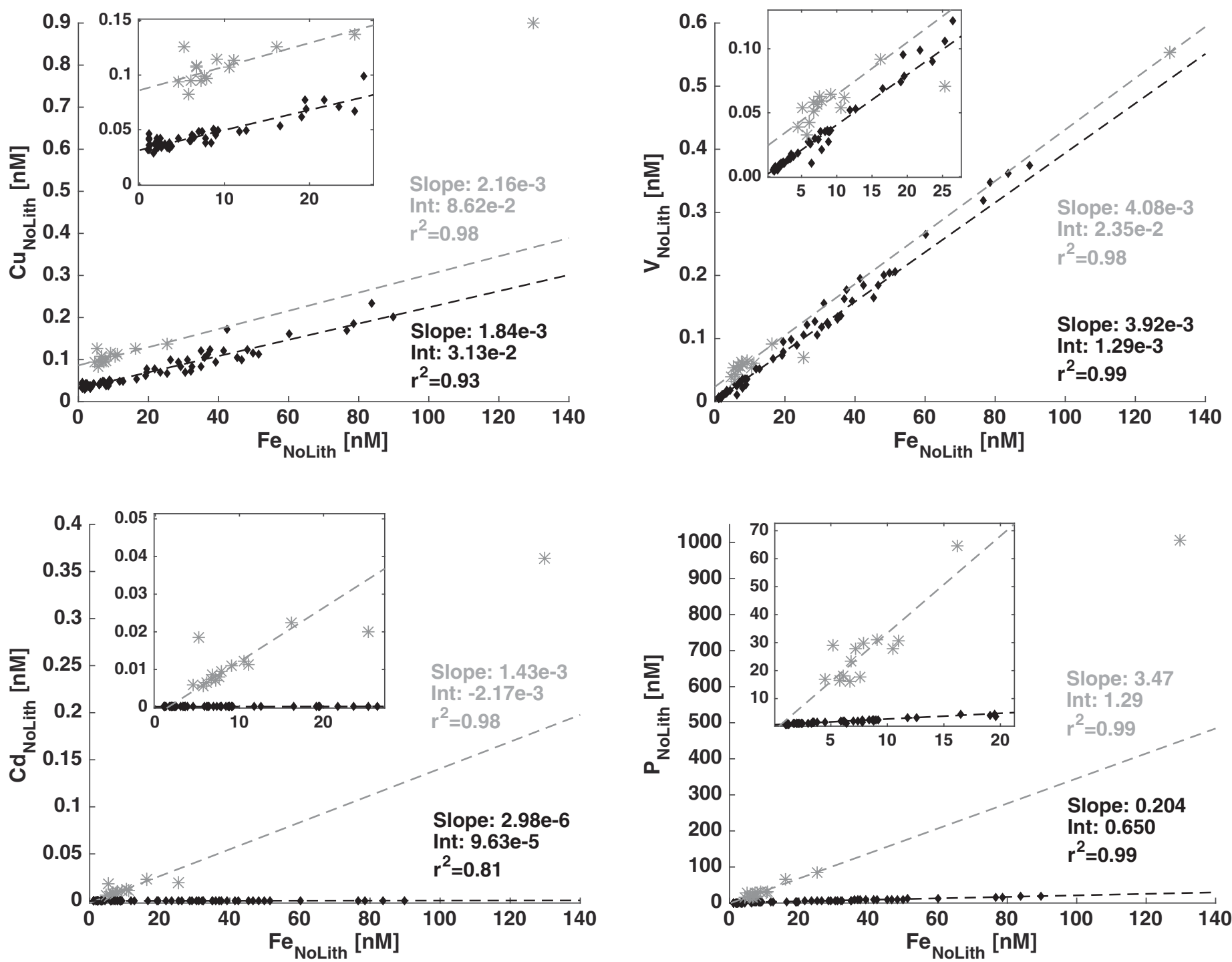

$\begin{array}{|cc|}* & \text { ODZ Shelf } \\ -- & \text { (fit) } \\ - & \text { HT Plume } \\ --\quad \text { (fit) }\end{array}$

Fig. 6. Scatterplots of select bioactive pTMs (Cd, $P, C u$, and $V ; y$-axes) vs. particulate Fe (x-axes) after correction for only lithogenic abundances ("NoLith") in shelf ODZ samples (gray asterisks) and samples from the East Pacific Rise hydrothermal plume (Sta. 18-26, 2000-2800 m depth, pFe $>1 \mathrm{nM}$; black diamonds). Robust linear regressions (MATLAB, which iteratively re-weights samples to remove the influence of outliers [Holland and Welsch 1987]) and $r^{2}$ values for the fits are shown (color coded lines, text). Insets: close-up views of the lower ends of the distributions.

elements corrected only for lithogenic phases (Fe and Mn, as needed) are referred to as “_NoLith."

\section{Particulate trace metals (pTMs) in the ODZ}

Local maxima in many bioactive pTMs $(\mathrm{Cd}, \mathrm{Co}, \mathrm{Cu}, \mathrm{Ni}$, $\mathrm{V}$, and $\mathrm{Zn}$ ) were coincident with ODZ P/biomass enrichments, suggesting elevated biotic accumulation of trace metals by ODZ organisms. These enrichments remain even after correction for lithogenic and ferruginous phases (Fig. 7). Median stoichiometries for the heterotrophic, non-fluores- cent ODZ biomass sampled at Sta. 11-13 (solid lines, Fig. 7) are between 2.8 and 8.6 times higher than those of transectmedian mixed layer biomass (dashed lines, Fig. 7), with these two end-members constraining most particulate samples.

Our ferruginous correction using Fe-rich hydrothermal scavenging of particulate TMs is a best effort (high-end) constraint in that we have assumed that all Fe within the ODZ is ferruginous in nature. We can, however, examine the Fe abundances in ODZ particles corrected only for lithogenic 

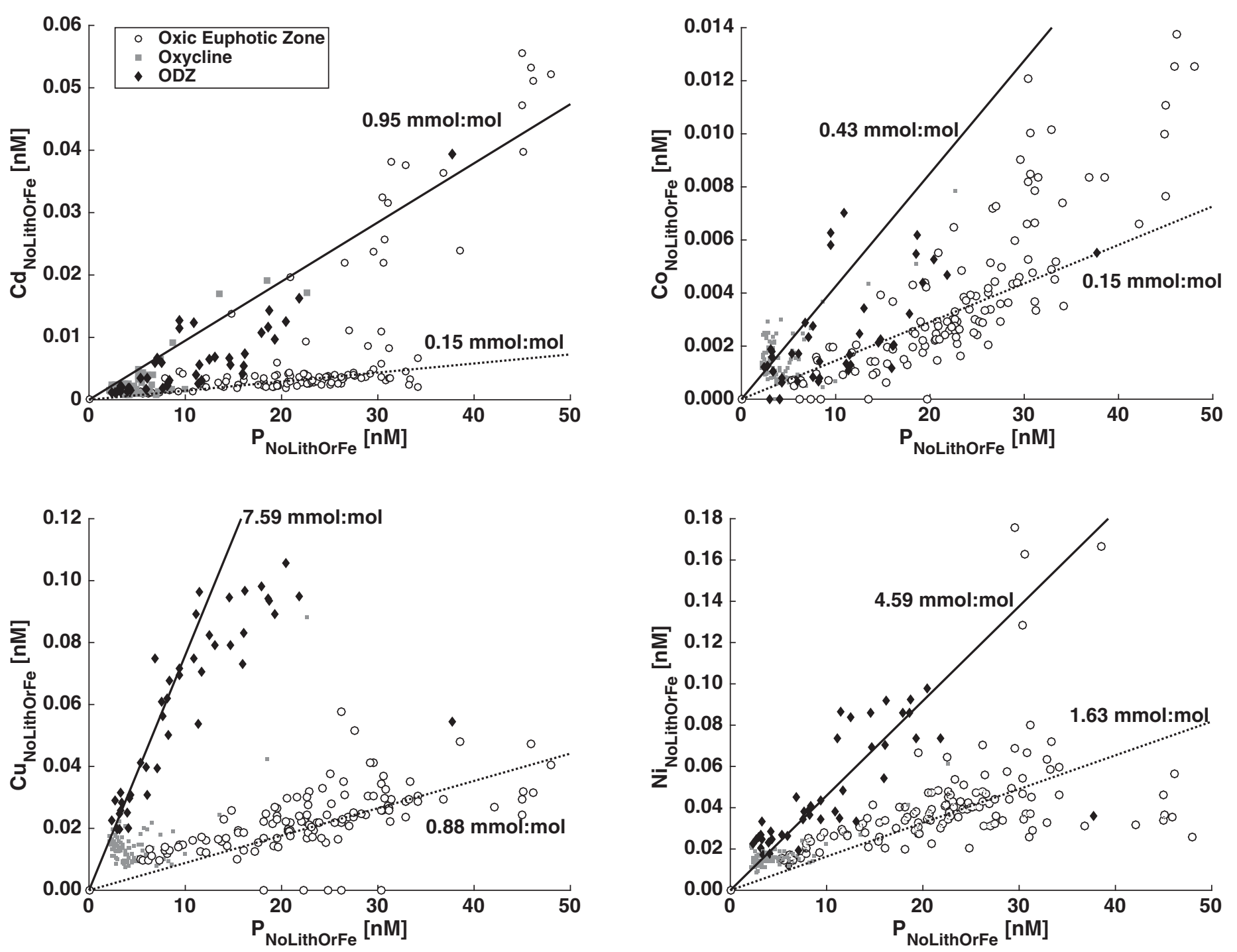

Fig. 7. Scatterplots of bioactive pTMs ( $y$-axes) vs. P ( $x$-axes) for all stations $\geq 6$ after correction for both lithogenic and ferruginous phases ("_NoLithOrFe"), except Fe and Mn which have been corrected for only lithogenic phases ("_NoLith") (see next page). Shading and shapes are as in Fig. 4: white circles: oxic euphotic zone (oxygen saturation $\geq 90 \%$ ); grey squares: upper oxycline; black diamonds: ODZ. Trendlines and annotations (slopes) show the transect-median mixed layer stoichiometry (dashed line) and median ODZ stoichiometry observed at Sta. 11-13 (solid line), which only exhibited heterotrophic biomass.

material relative to $\mathrm{P}$ (Fig. 7, Fe:P) to look for possible trends in Fe usage and/or scavenging. Doing so, we find a Fe:P ratio of 39.7 mmol:mol in the heterotrophic ODZ samples of Sta. 11-13 (solid line, Fig. 7, Fe:P), while stations nearer shore exhibited much higher Fe:P ratios (points above the line, Fig. 7, Fe:P) demonstrating greater loading of ferruginous particles in the eastern ODZ. It remains to be demonstrated how (or if) this higher ferruginous content is associated with the autotrophy present in eastern ODZs. One possible link is through the stronger secondary nitrite maxima at those stations: metabolic Fe(II) oxidation, and, in some species, mineral encrustation of cells, have been observed in mixotrophic denitrifying bacteria (Klueglein et al. 2014) that may be present in such communities.
Relatedly, though the ferruginous phase can account for all $\mathrm{Mn}$ in the ODZ (Table 2), so too can the biotic phase (Fig. 7, Mn). Prior to ferruginous correction of Mn, nearly all ODZ biomass exhibits a stoichiometry of $\sim 1 \mathrm{mmol} \mathrm{Mn} / \mathrm{mol}$ $\mathrm{P}$, similar to the Mn content exhibited by surface mixed layer biota (dashed line, Fig. 7, Mn). It thus appears possible that all of the picomolar-level Mn found in the ETSP ODZ may be in association with biotic material, rather than with ferruginous phases.

Figure 8 presents the stoichiometries in upper ODZ samples from each station after correction for lithogenic and ferruginous content. Stoichiometric trends in the surface mixed layer and non-ODZ oxygen minima (west of Sta. 13) are also provided for context. Given the absence of fluorescence at 

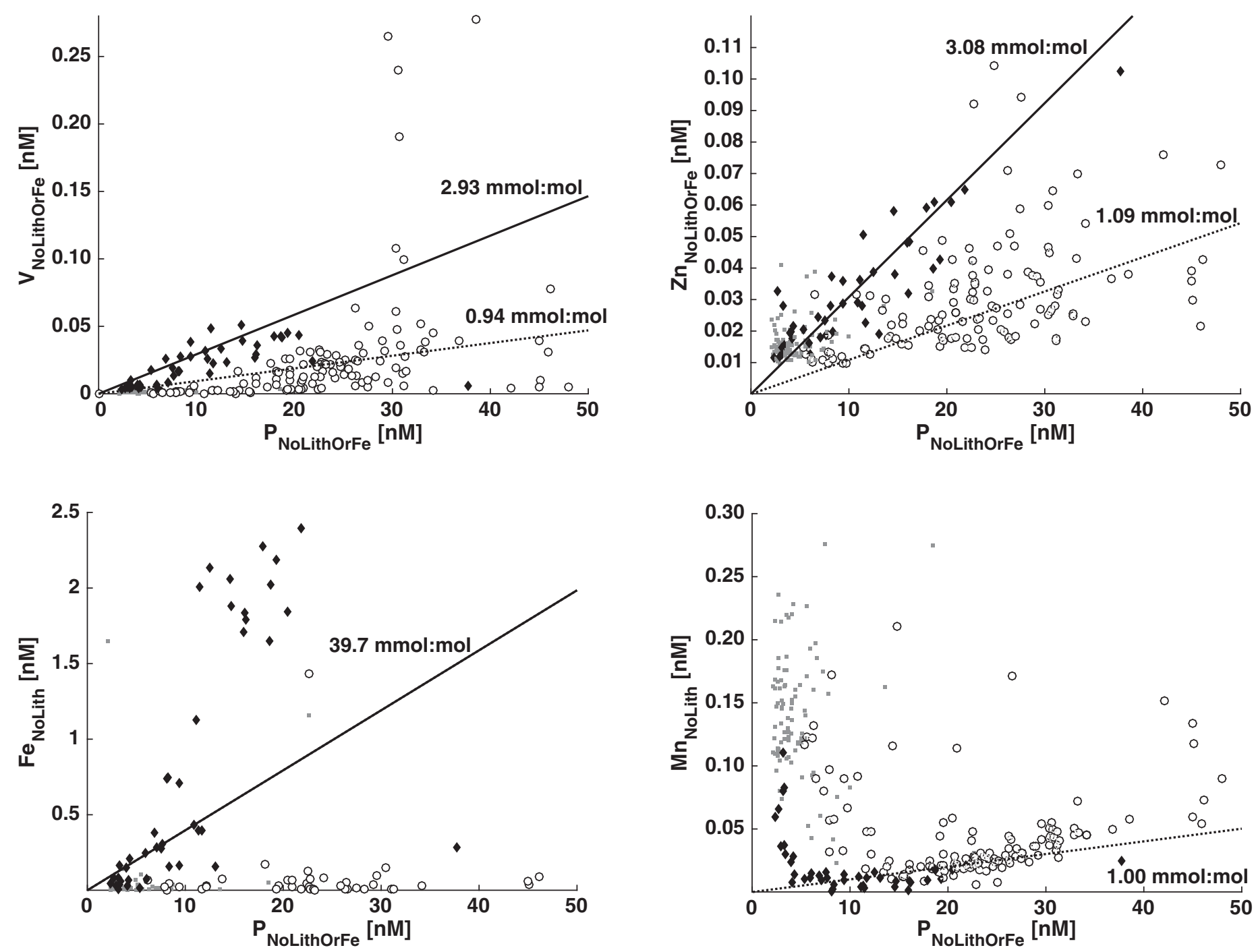

Fig. 7. (continued)

Sta. 11-13, and the elevated metal:P ratios seen in many samples there, we further delineate the offshore ODZ stations into those exhibiting fluorescence ("autotrophic ODZ", Sta. 6-10) and those without ("heterotrophic ODZ", Sta. 1113). P-normalized stoichiometries are summarized by region in Table 3, which provides medians and standard deviations for mixed layer (ML) and ODZ samples, as well as ODZ/ML ratios.

The Cd:P and Co:P ratios of heterotrophic ODZ biomass in the upper ODZ at Sta. 11-13 are notably elevated compared to stations with shallower, autotrophic ODZ biomass to the east. At the autotrophic ODZ stations, the highest Cd and Co quotas are found in fluorescent, upper ODZ samples which also roughly follow surface mixed layer trends, especially for Co, perhaps reflecting the presence of Prochlorococcus cells in both the upper ODZ and the mixed layer. Nonfluorescent, deeper ODZ samples, which are likely hetero- troph-dominated, are generally lower in $\mathrm{Cd}$ and Co. Elevated $\mathrm{Cd}$ and Co quotas at Sta. 11-13 may be somehow linked to the absence of autotrophic biomass there, to their location at the top of the ODZ, or perhaps associated with station or depth-specific organism(s) not discernable in our dataset.

The other metals $(\mathrm{Cu}, \mathrm{Ni}, \mathrm{V}$, and $\mathrm{Zn})$ show more consistent trends across heterotrophic and autotrophic ODZ biomass and are also more consistently distinct in composition from mixed layer biota. Copper stoichiometries appear somewhat enriched in deeper, non-fluorescent ODZ samples, with $\mathrm{Cu}: \mathrm{P}$ typically reaching a maximum between $30 \mathrm{~m}$ and $60 \mathrm{~m}$ into the ODZ (annotations, Fig. 8, Cu:P), and are also somewhat higher at Sta. 11-13. This may reflect elevated $\mathrm{Cu}$ demand, a shift in $\mathrm{Cu}$ speciation/bioavailability, or $\mathrm{Cu}$ accumulation by heterotrophic organisms living in the ODZ core compared to the autotrophic-dominated upper ODZ. 

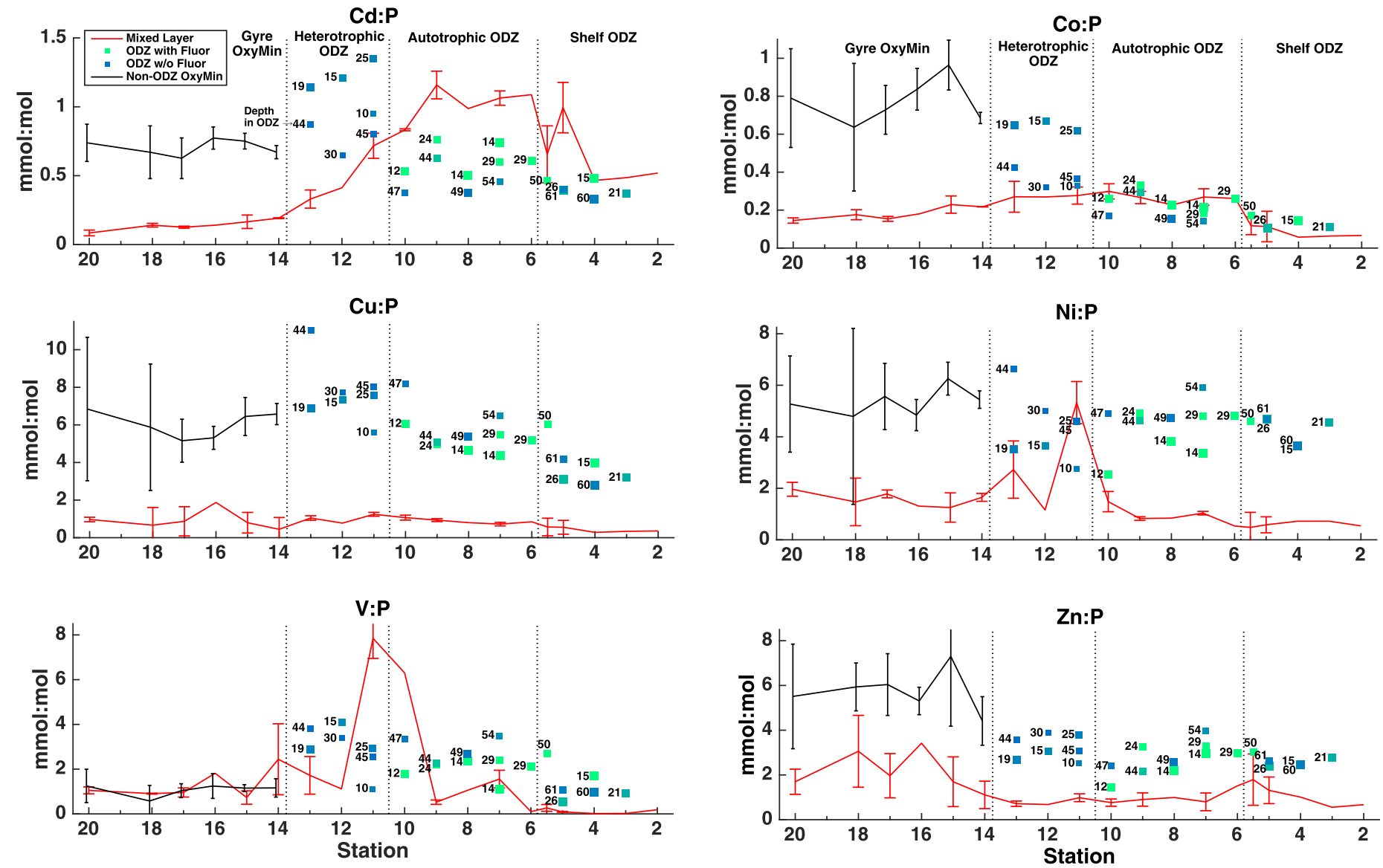

Fig. 8. Element:P ratios in upper ODZ samples (individual points, mmol:mol P) compared to surface mixed layer samples (red line) and gyre Sta. 1420 oxygen minimum samples (black line; $250-400 \mathrm{~m}$ depth). All ratios plotted have been corrected for lithogenic and ferruginous phases. Error bars for surface mixed layer and gyre oxygen minima represent one standard deviation from the station median. Text annotations indicate sample depth in meters below the upper limit of the ODZ. Symbol shading indicates fluorescence intensity: ODZ samples with fluorescence are shaded green and samples without fluorescence are blue. From right to left, vertical lines separate the shelf ODZ stations $(<6)$, fluorescent/autotrophic ODZ stations (6-10), non-fluorescent/heterotrophic ODZ stations (11-13) and gyre stations (>13).

Interestingly, recent meta-omic results predict the opposite effect, with greater $\mathrm{Cu}$ demand expected for upper ODZ species and greater Fe demand in the ODZ core (Glass et al. 2015).

ODZ Ni quotas are also rather consistent across the transect and with depth in the ODZ, at between 2 and 7 mmol:mol, and are enriched compared to the mixed layer (generally $<2$ mmol:mol). Saito et al. (2014) attributed significant Ni utilization in this region to Prochlorococcus nickel superoxide dismutase (Ni-SOD), which may contribute to the constancy in autotrophic ODZ Ni stoichiometries. SOD has been shown to be constitutively expressed in some anaerobic marine organisms (Dolla et al. 2006) and may be necessary for dealing with the oxidative stress induced by free metals.

A link between decreased $\mathrm{Zn}$ availability and Cd substitution in carbonic anhydrase is known in phytoplankton (Cullen and Sherrell 2005) and this effect appears in our dataset as an anti-correlation between mixed layer $\mathrm{Zn}$ and
Cd quotas (Fig. 8, Cd and Zn, red lines). The same effect does not appear obvious for the ODZ prokaryotic communities, however: the most elevated ODZ Cd quotas, seen at Sta. 11-13, do not appear to be associated with abnormally low $\mathrm{Zn}$ quotas, indicating a decoupling between $\mathrm{Cd}$ and $\mathrm{Zn}$ demand in the subsurface. Similar to Ni, ODZ Zn stoichiometries are consistently enriched compared to the oxic euphotic zone, suggesting that prokaryotic communities maintain higher standing stoichiometries of this metal.

Across all elements, we note that ODZ stoichiometries in the heterotrophic ODZ of Sta. 11-13 are similar to the bulk particle stoichiometries observed at the oxygen minima of non-ODZ gyre stations to the west (black lines in Fig. 8), which lack the distinct local maxima in P and pTMs seen in the ODZ. We have isolated the local maxima in P and pTMs for the heterotrophic biomass at Sta. 11-13 by subtracting linear profile backgrounds. This heterotrophic-only prokaryotic signature (Table 3, "Bkgr. Corr" values) is similar to (Co 
and $\mathrm{Ni}$ ) or greater than $(\mathrm{Cd}, \mathrm{Cu}$, and $\mathrm{V})$ the typical ranges for gyre oxygen minimum particles seen in Fig. 8, and are slightly lower for Zn. Whether any of the P-normalized stoichiometries we report for ODZ prokaryotic communities are descriptive of metal demands by more globally distributed oxygen minimum prokaryotic communities, however, will require more direct investigation.

\section{Mn oxyhydroxides and acid-volatile sulfides \\ Authigenic Mn oxides and comparisons to the Black Sea}

Particulate Mn exhibits strong depletion within the ETSP ODZ, indicating reductive dissolution of upper oxyclinesourced Mn oxyhydroxides as these particles settle into the suboxic zone (Figs. 3C,D, 7, Mn:P). Some low picomolarlevel particulate $\mathrm{Mn}$ may be retained internally by ODZ biota in stoichiometric trends similar to those observed in surface biomass (Fig. 7, Mn), or possibly in association with ferruginous phases. The apparent lack of exposed Mn oxyhydroxides in a way simplifies the ODZ particulate regime: we can ignore authigenic $\mathrm{Mn}$, which is known to scavenge $\mathrm{Co}$ and $\mathrm{Pb}$ (Sherrell and Boyle 1992; Noble et al. 2015). The absence of $\mathrm{Mn}$ oxyhydroxides in the ODZ is also in stark contrast to the Mn-rich suboxic/ferruginous zones of the Black Sea and Cariaco Basin systems, where Mn oxyhydroxides and Fe oxyhydroxides coexist at nM levels (Lewis and Landing 1991, 1992; Yiğiterhan et al. 2011). In the Black Sea suboxic zone these high levels of authigenic carrier phases (24-138 nM particulate $\mathrm{Mn}, 7-27 \mathrm{nM}$ particulate $\mathrm{Fe}$ [Yiğiterhan et al. 2011]) likely overwhelm any biological signals, and the presence of a thick euxinic layer beneath the Black Sea suboxic/ferruginous zone further complicates the dissolved and particulate trace metal fluxes there. This makes direct compositional comparisons between the systems difficult and highlights the potentially unique nature of the ETSP with respect to biogenic metal accumulation and speciation.

The near-complete ODZ-associated loss of Mn also provides a sharp boundary in basin-scale pTM distributions: west of $100^{\circ} \mathrm{W}, \mathrm{Mn}$ oxides produced in the upper oxycline persist in the upper water column as there is no suboxic layer to remove them as they settle. East of $100^{\circ} \mathrm{W}$, upper oxycline-sourced Mn oxides are reduced in the ODZ and can only re-form in the lower oxycline beneath the ODZ (and then, only at stations deep enough to have such a feature). This may affect pTM scavenging in the region, especially for the micronutrient Co (Hawco et al. 2016), which is scavenged by $\mathrm{Mn}$. The eastward vertical compression of the upper oxycline may also affect the intensity of Mn (and thus Co) removal as the total volume available for Mn scavenging decreases. Scavenging by Mn may also differ between the upper vs. lower oxyclines, perhaps due to the presence of different dissolved TM pools in each region. Shoaling of the ODZ over time, as has already been observed in response to climate change (Stramma et al. 2012), may further influence these effects.

\section{Acid-volatile sulfides}

We also examined the concentrations of acid-volatile sulfides (AVS), which were analyzed at sea on freshly filtered samples collected by in situ pumps on separate casts at many stations. The AVS method quantifies the sum of many mono-sulfide phases (FeS, ZnS, NiS, and CdS) but not $\mathrm{CuS}$, $\mathrm{HgS}$, or mixed-valence sulfides such as pyrite. AVS concentrations are plotted vs. oxygen saturation in Fig. 9a. In the upper $1000 \mathrm{~m}$ of the transect, AVS concentrations ranged between $0.5 \mathrm{pM}$ and $264 \mathrm{pM}$ (median: $3.6 \mathrm{pM}$; mean $\pm 1 \mathrm{SD}$ : $25 \mathrm{pM} \pm 50 \mathrm{pM}$ ) which is stoichiometrically low in abundance compared to most sulfide-forming pTMs (Fig. 9B). Particulate $\mathrm{Ni}$ and $\mathrm{Zn}$ were typically in great stoichiometric excess to AVS in the euphotic zone and the ODZ, where stoichiometric ratios of $\leq 1: 1$ would be expected if sulfides were the only, or dominant, particulate carrier for these elements. For visual clarity, and due to the ferruginous phases known to be present at most ODZ stations, Fe:AVS ratios (median: 74 mol:mol, range: $2.2-1800$ mol:mol) are not plotted in Fig. 9B.

Cadmium:AVS abundances were well above 1:1 mol:mol in the oxic euphotic zone but generally $\leq 1: 1$ in the ODZ (Fig. 9C), implying the potential for a sulfide carrier phase there. Recent work (Janssen et al. 2014) has indicated a potential sulfide carrier for particulate $\mathrm{Cd}$ enrichments observed in Atlantic basin oxygen minima where they are thought to form in the low-oxygen microenvironments of larger sinking particles, even when ambient water column oxygen concentrations are $>50 \mu \mathrm{M}$. These sulfides may then persist in the water column as fine $\mathrm{Cd}$-rich particles once the larger sinking particles have remineralized. In this transect, we expected to see evidence for these processes in the ODZ particle environment, where active $S$ cycling is thought to occur (Ulloa et al. 2012). Given the low (generally $<100 \mathrm{pM}$ ) concentrations of AVS in the ODZ, it appears that typically half of AVS present, and frequently all of it, would need to be bound to Cd to account for both phases' abundances (mean ODZ Cd:AVS ratio: $0.43 \pm 0.27 \mathrm{~mol}: \mathrm{mol})$, at the near total exclusion of the other AVS-forming elements ( $\mathrm{Ni}, \mathrm{Zn}$, and $\mathrm{Fe}$ ) that exhibit great stoichiometric excesses to $\mathrm{Cd}$ and AVS at the same depths. Although stoichiometrically feasible, the $\leq 1: 1$ relationship observed for Cd:AVS in ODZ particles is alone not convincing evidence for a dominant sulfide carrier for this single element, at least in the suboxic environment of the ETSP.

Abundances of AVS in the ODZ do appear to show a relationship with particulate $P$, however, exhibiting ratios of $\approx 1$ mmol AVS:mol P throughout the ODZ (Fig. 9D). This indicates a potential biotic carrier phase for much of the observed AVS in the ODZ, as also indicated previously for 

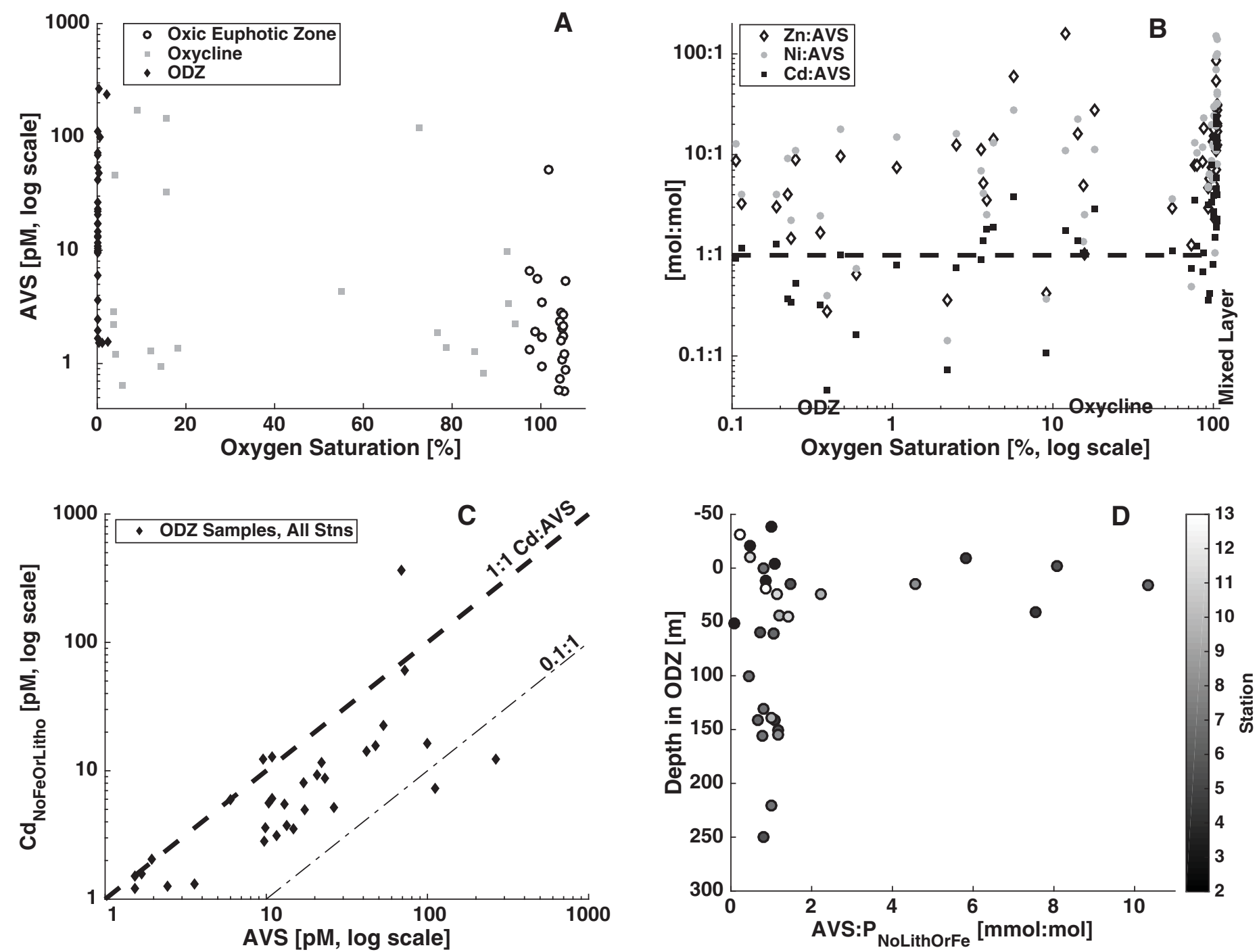

Fig. 9. (A) Concentrations of AVS (pM, log scale) plotted as a function of oxygen saturation (\%). Surface AVS concentrations are indicative of mixed layer AVS sources associated with assimilatory sulfate reduction during photosynthesis. Elevated concentrations near the ODZ, observed through Sta. 13, may also indicate AVS accumulation due to dissimilatory sulfate reduction (the "cryptic sulfur cycle"), though autotrophic processes also occur at many upper ODZ depths. (B, C) Element-specific metal:AVS ratios (mol:mol, log scale; after litho- and ferruginous correction) as a function of oxygen saturation (\%, log scale). Black squares, Cd:AVS; gray circles, Ni:AVS; white diamonds, Zn:AVS. Dashed line: 1:1 expected stoichiometric ratio for metal:sulfide phases. Nearly all euphotic and ODZ samples have Ni:S, Zn:S, and Fe:S (not shown) ratios greater than 1:1, implicating dominance of non-sulfidic particulate carrier phases for those elements. Cd:AVS ratios are consistently greater than 1:1 in the euphotic zone, but generally $\leq 1: 1$ within the ODZ (C, dotted reference line). (D) In most ODZ samples, AVS concentrations exhibit a fairly consistent particulate AVS/P ratio $(\approx 1 \mathrm{mmol}: \mathrm{mol})$ indicating a predominantly biotic carrier. Elevated AVS:P samples occasionally seen in the upper ODZ at several stations may indicate transient free sulfides, though AVS concentrations never exceeded 265 pM.

many pTMs. Occasionally elevated "flier" AVS concentrations (>100 pM; AVS:P > 4 mmol:mol, Fig. 9D), sometimes observed in the upper $50 \mathrm{~m}$ of the ODZ, may indeed be local free sulfide maxima related to $\mathrm{S}$-cycling processes that are difficult to reliably sample with discrete bottles. Taken as a whole, however, the limited carrying capacity of observed AVS phases, from a broad sampling of ODZ depths across the transect, suggests that sulfides are minor and/or transient contributors to bulk pTM carrying capacity compared to biotic (P-rich) particles.

\section{Community complexity and dataset limitations}

Most prokaryotic ODZ organisms are known via their genetic fingerprints (Ulloa et al. 2012), and few have been assessed with regards to their trace metal associations, either in field studies or trace metal-controlled laboratory cultures. Our observations of consistent P-maxima, pTM-maxima, and elevated pTM quotas throughout the ETSP ODZ provides a first look at the bulk trace metal associations of these under-sampled ecosystems. Our measurements reveal consistent patterns of elevated trace metal associations by 
biogeochemically important, prokaryote-rich communities. At many stations, ODZ communities expressed elevated stoichiometries for the bioactive trace metals $\mathrm{Cd}, \mathrm{Co}, \mathrm{Cu}, \mathrm{Ni}, \mathrm{V}$, and $\mathrm{Zn}$ compared to euphotic zone eukaryotic phytoplankton (Twining and Baines 2013).

Although we conclude that many pTM enrichments found in the ODZ are associated with microbial biomass, these communities are also known to be taxonomically and biochemically complex. ODZ ecosystems conduct vertically compressed, if not overlapping, redox cycling of $\mathrm{O}, \mathrm{N}$ (nitrate/nitrite/ammonium), Mn, and "cryptic" S (Canfield et al. 2010), among other potential redox acceptors. Eastern stations display significant autotrophic fluorescence at upper ODZ depths, while deeper stations to the west exhibit biomass maxima without autotrophy, suggesting heterotrophic communities only. Our bulk digestions of filtered particles from these complex communities are thus limited to interpretation at the broad ecosystem level, rather than directly informing about metal utilization by specific organisms.

\section{Remaining questions}

Several questions naturally emerge from our observations of elevated prokaryotic pTM observations within ODZs. Are these elevated particulate TM:P ratios unique to ODZ prokaryotes, and do they occur because of access to generally larger inventories of dissolved TMs in the subsurface? Denitrifying and other $\mathrm{N}$-cycling ODZ biota are expected to have unique biochemical/enzymatic demands for trace metals (Moffett et al. 2007; Glass et al. 2015), so access to stable, elevated dissolved metal pools may support niche anaerobic respirations. In essence, the unique biogeochemical environment of the ODZ may have produced unique biotic stoichiometries, perhaps even reflective of the ancient anoxic ocean (Saito et al. 2003). An additional, non-mutually exclusive possibility is that luxury uptake of micronutrient metals is more general beneath the euphotic zone, as has been shown for $\mathrm{Cd}$ and $\mathrm{Zn}$ in the Ross Sea (Saito et al. 2010). The metal requirements and stoichiometric flexibilities of prokaryotes must be more rigorously examined to determine if elevated pTM associations are unique to the ODZ and which metal enrichments are associated with which organisms. If elevated pTM stoichiometries are common to prokaryotes found more widely throughout the water column (e.g., Fig. 8; gyre oxymin stoichiometries), their stoichiometries would provide a starkly different biomass compositional end-member than those of phytoplankton that are widely used in modeling experiments. Even if pTM enrichments are limited to ODZ biomass and are not common outside the ODZ, settling and remineralization of ODZ prokaryotic biomass into the deep ocean and underlying sediments may need to be considered separately when parameterizing local metal fluxes.

Future work should help constrain corrections for scavenged, authigenic, ferruginous minerals such as ferrihydrite and lepidocrocite (Senn et al. 2015) which have higher con- centrations and greater influence on particle speciation nearer the shelf. Although biomass concentrations (via P) exceeded those of ferruginous phases throughout the ODZ, ferruginous pTM scavenging remains a complicating factor in understanding this water column particle regime. Nevertheless, separation of the various particulate phases as attempted here is perhaps simpler in the ETSP than in the authigenic $\mathrm{Mn}-$, Fe-, and sulfide-rich suboxic zones of the Black Sea and Cariaco Basin.

How do elevated-pTM associations in ODZ biomass relate to local and global cycling of pTMs throughout the oceans? At shallower, margin-associated sites ODZs directly interact with sediments, so deposition and preservation of pTM-rich prokaryotic biomass could influence the sedimentary record of these metals. We observed that metal:P ratios of ODZ communities are typically elevated, sometimes many fold, vs. mixed layer communities (Table 3), with metal stoichiometries highest at the heterotrophic-dominated ODZs of Sta. 11-13 (Table 3, "Bkgr. Corr." stoichiometries). Though large, sinking particle production is presumably diminished within the ODZ due to the exclusion of grazers, persistent settling fluxes of fine, metal-rich biomass (or their adherence to particles sinking through the ODZ) into the sediments may influence the sedimentary record of sites overlain by ODZs. Oxic autotrophic biomass production and vertical fluxes presumably dominate prokaryotic biomass signals in these highly productive regions, but the presence of prokaryotic end-members with elevated metal stoichiometries may still need to be considered during sedimentary interpretations of some bioactive metals, e.g., Ni (Böning et al. 2015).

The longitudinal extent of the ODZ and its microbial communities is ultimately dependent on the intensity of regional upwelling. In this transect of the ETSP along 12$13^{\circ} \mathrm{S}$, the ODZ and its TM-rich biota extended well beyond the region of shelf-associated productivity $(\approx 400 \mathrm{~km}$ offshore)—to as far as $2300 \mathrm{~km}$ offshore. Redfield-like metal utilization ratios, long presumed to be set by phytoplankton biomass in the surface ocean, have well recognized links to global metal cycles, deep water mass signatures, and broad oceanic composition (Morel 2008). Though these ODZ ecosystems and stoichiometries may be constrained to a limited oceanic volume, the potential for TM-rich prokaryotes to influence biomass/water-mass relationships on larger spatial scales remains unknown.

\section{References}

Allgaier, M., H. Uphoff, A. Felske, and I. Wagner-Dobler. 2003. Aerobic anoxygenic photosynthesis in Roseobacter clade bacteria from diverse marine habitats. Appl. Environ. Microbiol. 69: 5051-5059. doi:10.1128/AEM.69.9.5051-5059.

Béjà, O., and others. 2002. Unsuspected diversity among marine aerobic anoxygenic phototrophs. Nature 415: 630-633. doi:10.1038/415630a 
Benson, B. B., and D. Krause, Jr. 1984. The concentration and isotopic fractionation of oxygen dissolved in freshwater and seawater in equilibrium with the atmosphere. Limnol. Oceanogr. 29: 620-632. doi:10.4319/lo.1984. 29.3.0620

Bertrand, A., M. Ballon, and A. Chaigneau. 2010. Acoustic observation of living organisms reveals the upper limit of the oxygen minimum zone. PLoS ONE 5: e10330. doi: 10.1371/journal.pone.0010330

Binet, M., R. Ma, C. W. McLeod, and R. K. Poole. 2003. Detection and characterization of zinc-and cadmiumbinding proteins in Escherichia coli by gel electrophoresis and laser ablation-inductively coupled plasma-mass spectrometry. Anal. Biochem. 318: 30-38. doi:10.1016/S00032697(03)00190-8

Bishop, J., and T. J. Wood. 2009. Year-round observations of carbon biomass and flux variability in the Southern Ocean, Global Biogeochem. Cycles 23: GB2019. doi: 10.1029/2008GB003206

Böning, P., H. J. Brumsack, M. E. Böttcher, B. Schnetger, C. Kriete, J. Kallmeyer, and S. L. Borchers. 2004. Geochemistry of Peruvian near-surface sediments. Geochim. Cosmochim. Acta 68: 4429-4451. doi:10.1016/j.gca.2004.04.027.

Böning, P., T. Shaw, K. Pahnke, and H. J. Brumsack. 2015. Nickel as indicator of fresh organic matter in upwelling sediments. Geochim. Cosmochim. Acta 162: 99-108. doi: 10.1016/j.gca.2015.04.027

Canfield, D. E., F. J. Stewart, B. Thamdrup, L. De Brabandere, T. Dalsgaard, E. F. DeLong, N. P. Revsbech, and O. Ulloa. 2010. A cryptic sulfur cycle in oxygen-minimum-zone waters off the Chilean coast. Science 330: 1375-1378. doi:10.1126/science.1196889

Cho, B. C., and F. Azam. 1988. Major role of bacteria in biogeochemical fluxes in the ocean's interior. Nature 332: 441-443. doi:10.1038/332441a0

Close, H. G., S. G. Wakeham, and A. Pearson. 2014. Lipid and 13C signatures of submicron and suspended particulate organic matter in the Eastern Tropical North Pacific: Implications for the contribution of Bacteria. Deep-Sea Res., Part I 85: 15-34. doi:10.1016/j.dsr.2013.11.005

Cowen, J. P., and K. W. Bruland. 1985. Metal deposits associated with bacteria: Implications for $\mathrm{Fe}$ and $\mathrm{Mn}$ marine biogeochemistry, Deep-Sea Res., Part A 32: 253-272. doi: 10.1016/0198-0149(85)90078-0

Cullen, J. T., and R. M. Sherrell. 2005. Effects of dissolved carbon dioxide, zinc, and manganese on the cadmium to phosphorus ratio in natural phytoplankton assemblages. Limnol. Oceanogr. 50: 1193. doi:10.4319/lo.2005.50. 4.1193

Cutter, G. A., and T. J. Oatts. 1987. Determination of dissolved sulfide and sedimentary sulfur speciation using gas chromatography-photoionization detection. Anal. Chem. 59: 717-721. doi:10.1021/ac00132a008
Cutter, G. A., P. S. Andersson, L. A. Codispoti, P. L. Croot, R. Francois, M. C. Lohan, H. Obata, and M. M. Rutgers Van Der Loeff. 2010. Sampling and sample-handling protocols for GEOTRACES Cruises [Internet]. GEOTRACES; Toulouse, France. pp. 1-238. Available from http://www.geotraces.org/libraries/documents/Intercalibration/ Cookbook.pdf

Dixon, J. L., P. J. Statham, and C. E. Widdicombe. 2006. Cadmium uptake by marine micro-organisms in the English Channel and Celtic Sea. Aquat. Microb. Ecol. 44: 3143. doi:10.3354/ame044031

Dolla, A., M. Fournier, and Z. Dermoun. 2006. Oxygen defense in sulfate-reducing bacteria. J. Biotechnol. 126: 87-100. doi:10.1016/j.jbiotec.2006.03.041

Feely, R. A., J. H. Trefry, G. T. Lebon, and C. R. German. 1998. The relationship between $\mathrm{P} / \mathrm{Fe}$ and $\mathrm{V} / \mathrm{Fe}$ ratios in hydrothermal precipitates and dissolved phosphate in seawater. Geophys. Res. Lett. 25: 2253-2256. doi:10.1029/ 98GL01546

Fiedler, P. C., and L. D. Talley. 2006. Hydrography of the eastern tropical Pacific: A review. Prog. Oceanogr. 69: 143-180. doi:10.1016/j.pocean.2006.03.008

Francis, C. A., E. M. Co, and B. M. Tebo. 2001. Enzymatic manganese(II) oxidation by a marine alpha-proteobacterium. Appl. Environ. Microbiol. 67: 4024-4029. doi: 10.1128/AEM.67.9.4024-4029.2001

Fuhrman, J. A., T. D. Sleeter, C. A. Carlson, and L. M. Proctor. 1989. Dominance of bacterial biomass in the Sargasso Sea and its ecological implications. Mar. Ecol. Prog. Ser. 57: 207-217. doi:10.3354/meps057207

Galán, A., V. Molina, B. Thamdrup, D. Woebken, G. Lavik, M. M. M. Kuypers, and O. Ulloa. 2009. Anammox bacteria and the anaerobic oxidation of ammonium in the oxygen minimum zone off northern Chile. DeepSea Res. Part II 56: 1021-1031. doi:10.1016/j.dsr2. 2008.09.016

Glass, J. B., C. B. Kretz, S. Ganesh, and P. Ranjan. 2015. Meta-omic signatures of microbial metal and nitrogen cycling in marine oxygen minimum zones. Front. Microbiol. 6:998, doi:10.3389/fmicb.2015.00998

Goericke, R., R. J. Olson, and A. Shalapyonok. 2000. A novel niche for Prochlorococcus sp. in low-light suboxic environments in the Arabian Sea and the Eastern Tropical North Pacific. Deep-Sea Res., Part I 47: 1183-1205. doi: 10.1016/S0967-0637(99)00108-9

Gunnars, A., and S. Blomqvist. 1997. Phosphate exchange across the sediment-water interface when shifting from anoxic to oxic conditions an experimental comparison of freshwater and brackish-marine systems. Biogeochemistry 37: 203-226. doi:10.1023/A:1005744610602

Gunnars, A., S. Blomqvist, P. Johansson, and C. Andersson. 2002. Formation of Fe(III) oxyhydroxide colloids in freshwater and brackish seawater, with incorporation of 
phosphate and calcium. Geochim. Cosmochim. Acta 66: 745-758. doi:10.1016/S0016-7037(01)00818-3

Hawco, N. J., D. C. Ohnemus, J. A. Resing, B. S. Twining, and M. A. Saito. 2016. A cobalt plume in the oxygen minimum zone of the Eastern Tropical South Pacific. Biogeosci. Discuss. 1-60. doi:10.5194/bg-2016-169

Ho, T. Y., G. T. Taylor, Y. Astor, R. Varela, and F. MüllerKarger. 2004. Vertical and temporal variability of redox zonation in the water column of the Cariaco Basin: Implications for organic carbon oxidation pathways. Mar. Chem. 86: 89-104. doi:10.1016/j.marchem. 2003.11.002

Holland, P. W., and R. E. Welsch. 1987. Robust regression using iteratively reweighted least-squares. Commun. Stat. Theory Methods. 6: 813-827. doi:10.1080/0361092 7708827533

Hooker, S. B., and others. 2005. The second SeaWiFS HPLC analysis round-robin experiment (SeaHARRE-2). NASA Tech. Memo. 1-124.

Iyer, A., K. Mody, and B. Jha. 2005. Biosorption of heavy metals by a marine bacterium. Mar. Pollut. Bull. 50: 340343. doi:10.1016/j.marpolbul.2004.11.012

Janssen, D. J., T. M. Conway, S. G. John, J. R. Christian, D. I. Kramer, T. F. Pedersen, and J. T. Cullen. 2014. Undocumented water column sink for cadmium in open ocean oxygen-deficient zones. Proc. Natl. Acad. Sci. USA 111: 6888-6893. doi:10.1073/pnas.1402388111

Klueglein, N., F. Zeitvogel, Y. D. Stierhof, M. Floetenmeyer, K. O. Konhauser, A. Kappler, and M. Obst. 2014. Potential role of nitrite for abiotic Fe(II) oxidation and cell encrustation during nitrate reduction by denitrifying bacteria. Appl. Environ. Microbiol.. 80: 1051-1061. doi:10.1128/ AEM.03277-13

Lavin, P., B. González, J. F. Santibáñez, D. J. Scanlan, and O. Ulloa. 2010. Novel lineages of Prochlorococcus thrive within the oxygen minimum zone of the eastern tropical South Pacific. Environ. Microbiol. Rep. 2: 728-738. doi: 10.1111/j.1758-2229.2010.00167.x

Lewis, B. L., and W. M. Landing. 1991. The biogeochemistry of manganese and iron in the Black Sea. Deep-Sea Res., Part A 38: S773-S803. doi:10.1016/S0198-0149(10) 80009-3

Lewis, B. L., and W. M. Landing. 1992. The investigation of dissolved and suspended-particulate trace metal fractionation in the Black Sea. Mar. Chem. 40: 105-141. doi: 10.1016/0304-4203(92)90050-K

Llanillo, P. J., J. Karstensen, J. L. Pelegri, and L. Stramma. 2013. Physical and biogeochemical forcing of oxygen and nitrate changes during El Niño/El Viejo and La Niña/La Vieja upper-ocean phases in the tropical eastern South Pacific along $86^{\circ} \mathrm{W}$. Biogeosciences 10: 6339-6355. doi: 10.5194/bg-10-6339-2013

Mahowald, N. M., and others. 2008. Atmospheric iron deposition: Global distribution, variability, and human pertur- bations. Annu. Rev. Mar. Sci. 1: 245-278. doi:10.1146/ annurev.marine.010908.163727

Marra, J. F., V. P. Lance, R. D. Vaillancourt, and B. R. Hargreaves. 2014. Resolving the ocean's euphotic zone. Deep-Sea Res., Part I 83: 45-50. doi:10.1016/j.dsr. 2013.09.005

Moffett, J., T. Goepfert, and S. Naqvi. 2007. Reduced iron associated with secondary nitrite maxima in the Arabian Sea. Deep-Sea Res., Part I 54: 1341-1349. doi:10.1016/ j.dsr.2007.04.004

Morel, F. M. M. 2008. The co-evolution of phytoplankton and trace element cycles in the oceans. Geobiology 6: 318-324. doi:10.1111/j.1472-4669.2008.00144.x,

Nameroff, T. J., S. E. Calvert, and J. W. Murray. 2004. Glacial-interglacial variability in the eastern tropical North Pacific oxygen minimum zone recorded by redoxsensitive trace metals. Paleoceanography 19: PA1010, doi: 10.1029/2003PA000912

Naqvi, S., M. D. Kumar, and P. V. Narvekar. 1993. An intermediate nepheloid layer associated with high microbial metabolic rates and denitrification in the northwest Indian Ocean. J. Geophys. Res. 98: 16469-16479, doi: 10.1029/93JC00973

Noble, A. E., and others. 2015. Dynamic variability of dissolved $\mathrm{Pb}$ and $\mathrm{Pb}$ isotope composition from the U.S. North Atlantic GEOTRACES transect. Deep Sea Research Part II 116: 1-18. doi:10.1016/j.dsr2.2014.11.011

Ohnemus, D. C., and P. J. Lam. 2015. Cycling of lithogenic marine particles in the US GEOTRACES North Atlantic transect. Deep-Sea Res., Part II 116: 283-302. doi:10.1016/ j.dsr2.2014.11.019

Owens, S. A., S. Pike, and K. O. Buesseler. 2015. Thorium234 as a tracer of particle dynamics and upper ocean export in the Atlantic Ocean. Deep-Sea Res., Part II 116: 42-59. doi:10.1016/j.dsr2.2014.11.010.

Pak, H., L. A. Codispoti, and J. R. V. Zaneveld. 1980. On the intermediate particle maxima associated with oxygenpoor water off western South America. Deep-Sea Res., Part A Oceanogr. Res. Pap. 27: 783-797. doi:10.1016/01980149(80)90044-8

Planquette, H., and R. M. Sherrell. 2012. Sampling for particulate trace element determination using water sampling bottles: Methodology and comparison to in situ pumps. Limnol. Oceangr. Methods 10: 367-388. doi:10.4319/ lom.2012.10.367

Radford-Knoery, J., and G. A. Cutter. 1993. Determination of carbonyl sulfide and hydrogen sulfide species in natural waters using specialized collection procedures and gas chromatography with flame photometric detection. Anal. Chem. 65: 976-982. doi:10.1021/ac0005 $6 \mathrm{a} 005$

Repeta, D. J., D. J. Simpson, B. B. Jorgensen, and H. W. Jannasch. 1989. Evidence for anoxygenic photosynthesis 
from the distribution of bacterio-chlorophylls in the Black Sea. Nature 342: 69-72. doi:10.1038/342069a0

Resing, J. A., P. N. Sedwick, C. R. German, W. J. Jenkins, J. W. Moffett, B. M. Sohst, and A. Tagliabue. 2015. Basinscale transport of hydrothermal dissolved metals across the South Pacific Ocean. Nature 523: 200-203. doi: 10.1038 /nature 14577

Rossi, N., and J. L. Jamet. 2008. In situ heavy metals (copper, lead and cadmium) in different plankton compartments and suspended particulate matter in two coupled Mediterranean coastal ecosystems. Mar. Pollut. Bull. 56: 18621870. doi:10.1016/j.marpolbul.2008.07.018

Saito, M. A., D. M. Sigman, and F. M. M. Morel. 2003. The bioinorganic chemistry of the ancient ocean: the coevolution of cyanobacterial metal requirements and biogeochemical cycles at the Archean-Proterozoic boundary? Inorg. Chim. Acta 356: 308-318. doi:10.1016/S0020-1693 (03)00442-0

Saito, M. A., T. J. Goepfert, A. E. Noble, E. M. Bertrand, P. N. Sedwick, and G. R. DiTullio. 2010. A seasonal study of dissolved cobalt in the Ross Sea, Antarctica: Micronutrient behavior, absence of scavenging, and relationships with Zn, Cd, and P. Biogeosciences 7: 4059-4082. doi:10.5194/ bg-7-4059-2010

Saito, M. A., M. R. McIlvin, D. M. Moran, T. J. Goepfert, G. R. DiTullio, A. F. Post, and C. H. Lamborg. 2014. Multiple nutrient stresses at intersecting Pacific Ocean biomes detected by protein biomarkers. Science 345: 1173-1177. doi:10.1126/science. 1256450

Schmidt, M. A., and D. A. Hutchins. 1999. Size-fractionated biological iron and carbon uptake along a coastal to offshore transect in the NE Pacific. Deep-Sea Res., Part II 46: 2487-2503. doi:10.1016/S0967-0645(99)00073-9

Senn, A. C., R. Kaegi, S. J. Hug, J. G. Hering, S. Mangold, and A. Voegelin. 2015. Composition and structure of Fe (III)-precipitates formed by Fe (II) oxidation in water at near-neutral pH: Interdependent effects of phosphate, silicate and Ca. Geochim. Cosmochim. Acta 162: 220-246. doi:10.1016/j.gca.2015.04.032

Sherrell, R. M., and E. A. Boyle. 1992. The trace metal composition of suspended particles in the oceanic water column near Bermuda. Earth Planet. Sci. Lett. 111: 155-174. doi:10.1016/0012-821X(92)90176-V

Shirdam, R., A. Khanafari, and A. Tabatabaee. 2006. Cadmium, nickel and vanadium accumulation by three strains of marine bacteria. Iran J. Biotechnol. 4: 180-187.

Silva, N., N. Rojas, and A. Fedele. 2009. Water masses in the Humboldt Current System: Properties, distribution, and the nitrate deficit as a chemical water mass tracer for Equatorial Subsurface Water off Chile. Deep-Sea Res., Part II 56: 1004-1020. doi:10.1016/j.dsr2.2008.12.013

Spinrad, R. W., H. Glover, B. B. Ward, L. A. Codispoti, and G. Kullenberg. 1989. Suspended particle and bacterial maxima in Peruvian coastal waters during a cold water anomaly. Deep-Sea Res., Part A 36: 715-733. doi:10.1016/ 0198-0149(89)90147-7

Stramma, L., S. Schmidtko, L. A. Levin, and G. C. Johnson. 2010. Ocean oxygen minima expansions and their biological impacts. Deep-Sea Res., Part I 57: 587-595. doi: 10.1016/j.dsr.2010.01.005

Stramma, L., E. D. Prince, S. Schmidtko, and J. Luo. 2012. Expansion of oxygen minimum zones may reduce available habitat for tropical pelagic fishes. Nat. Clim. Change 2: 33-37. doi:10.1038/nclimate1304

Sunda, W. G., and S. A. Huntsman. 1995. Cobalt and zinc interreplacement in marine phytoplankton: Biological and geochemical implications. Limnol. Oceanogr. 40: 1404-1417, doi:10.4319/1o.1995.40.8.1404

Sunda, W. G., and S. A. Huntsman. 1997. Interrelated influence of iron, light and cell size on marine phytoplankton growth. Nature 390: 389-392, doi:10.1038/37093

Taylor, S. R., and S. M. McLennan. 1995. The geochemical evolution of the continental crust. Rev. Geophys. 33: 241-265. doi:10.1029/95RG00262

Tiano, L., E. Garcia-Robledo, and T. Dalsgaard. 2014. Oxygen distribution and aerobic respiration in the north and south eastern tropical Pacific oxygen minimum zones. Deep-Sea Res. 94: 173-183. doi:10.1016/j.dsr.2014.10.001

Toner, B. M., P. J. Lam, S. L. Nicholas, D. Ohnemus, C. L. Hoffman, J. N. Fitzsimmons, R. M. Sherrell, and C. R. German. 2014. The speciation of particulate iron and carbon in the East Pacific Rise $15^{\circ} \mathrm{S}$ near-field hydrothermal plume and underlying sediments. AGU Fall Meeting Abstr. OS23E-1267.

Tortell, P. D., M. T. Maldonado, and N. M. Price. 1996. The role of heterotrophic bacteria in iron-limited ocean ecosystems. Nature 383: 330-332. doi:10.1038/383330a0

Trefry, J. H., and S. Metz. 1989. Role of hydrothermal precipitates in the geochemical cycling of vanadium. Nature 342: 531-533, doi:10.1038/342531a0

Tribovillard, N., T. J. Algeo, T. Lyons, and A. Riboulleau. 2006. Trace metals as paleoredox and paleoproductivity proxies: an update. Chem. Geol. 232: 12-32. doi:10.1016/ j.chemgeo.2006.02.012

Twining, B. S. B., and S. B. S. Baines. 2013. The trace metal composition of marine phytoplankton. Annu. Rev. Mar. Sci. 5: 191-215. doi:10.1146/annurev-marine-121211172322

Twining, B. S., S. Rauschenberg, P. L. Morton, D. C. Ohnemus, and P. J. Lam. 2015. Comparison of particulate trace element concentrations in the North Atlantic Ocean as determined with discrete bottle sampling and in situ pumping. Deep-Sea Res. Part II 116, 273-282, doi: 10.1016/j.dsr2.2014.11.005

Ulloa, O., Canfield, D. E. DeLong, E. F. Letelier, R. M. Stewart, and F. J. Microbial. oceanography of anoxic oxygen minimum zones. Proc. Natl. Acad. Sci. 109: 15996-16003, doi:10.1073/pnas.1205009109, 2012. 
Vogel, C., and N. S. Fisher. 2010. Metal accumulation by heterotrophic marine bacterioplankton. Limnol. Oceanogr. 55: 519-528. [online] Available from: http://m.avto.aslo. info/lo/toc/vol_55/issue_2/0519.pdf, doi:10.4319/lo.2009. 55.2.0519

Wagener, T., C. Guieu, R. Losno, S. Bonnet, and N. Mahowald. 2008. Revisiting atmospheric dust export to the Southern Hemisphere ocean: Biogeochemical implications. Global Biogeochem. Cycles 22: GB2006. doi: 10.1029/2007GB002984.

Whitmire, A. L., R. M. Letelier, V. Villagrán, and O. Ulloa. 2009. Autonomous observations of in vivo fluorescence and particle backscattering in an oceanic oxygen minimum zone. Opt. Express 17: 21992-22004, doi:10.1016/ j.dsr2.2008.11.001.

Whitney, F. A., H. J. Freeland, and M. Robert. 2007. Persistently declining oxygen levels in the interior waters of the eastern subarctic Pacific. Prog. Oceanogr. 75: 179199. doi:10.1016/j.pocean.2007.08.007

Williams, R. L., S. Wakeham, and R. McKinney. 2014. Trophic ecology and vertical patterns of carbon and nitrogen stable isotopes in zooplankton from oxygen minimum zone regions. Deep-Sea Res., Part I 90: 36-47. doi: 10.1016/j.dsr.2014.04.008

Wishner, K. F., C. J. Ashjian, C. Gelfman, M. M. Gowing, L. Kann, L. A. Levin, L. S. Mullineaux, and J. Saltzman. 1995. Pelagic and benthic ecology of the lower interface of the Eastern Tropical Pacific oxygen minimum zone. Deep-Sea Res., Part I 42: 93-115. doi:10.1016/09670637(94)00021-J
Wishner, K. F., D. M. Outram, B. A. Seibel, and K. L. Daly. 2013. Zooplankton in the eastern tropical north Pacific: Boundary effects of oxygen minimum zone expansion. Deep-Sea Res. 79: 122-140. doi:10.1016/ j.dsr.2013.05.012.

Wright, J. J., K. M. Konwar, and S. J. Hallam. 2012. Microbial ecology of expanding oxygen minimum zones. Nat. Rev. Microbiol. 10: 381-394. doi:10.1038/nrmicro2778

Yiğiterhan, O., J. W. Murray, and S. Tuğrul. 2011. Trace metal composition of suspended particulate matter in the water column of the Black Sea. Mar. Chem. 126: 207228. doi:10.1016/j.marchem.2011.05.006

\section{Acknowledgments}

We greatly thank the captain and crew of the R/V Thomas $G$. Thompson, cruise TT303 as well as Phoebe Lam and the US Pacific GEOTRACES pumping team for subsamples used in AVS analyses. Conversations with Phoebe Lam and Nick Hawco and the insightful comments of two reviewers greatly improved the manuscript. Analytical support at the University of Maine was provided by Mike Handley. Funding was provided by the US and International GEOTRACES programs, via National Science Foundation grants OCE-1232814 to B.S.T., OCE-1235328 to G.A.C., and OCE-1234827 to R.M.S.

\section{Conflict of Interest}

None declared.
Submitted 26 August 2015 Revised 31 March 2016 Accepted 10 May 2016

Associate editor: Mary Scranton 